\title{
Attribution of recent ozone changes in the Southern Hemisphere mid-latitudes using statistical analysis and chemistry-climate model simulations
}

\author{
Guang Zeng $^{1}$, Olaf Morgenstern ${ }^{1}$, Hisako Shiona ${ }^{2}$, Alan J. Thomas ${ }^{3}$, Richard R. Querel ${ }^{3}$, and Sylvia E. Nichol ${ }^{1}$ \\ ${ }^{1}$ National Institute of Water and Atmospheric Research, Wellington, New Zealand \\ ${ }^{2}$ National Institute of Water and Atmospheric Research, Christchurch, New Zealand \\ ${ }^{3}$ National Institute of Water and Atmospheric Research, Lauder, New Zealand \\ Correspondence to: Guang Zeng (guang.zeng@niwa.co.nz)
}

Received: 26 April 2017 - Discussion started: 2 May 2017

Revised: 28 July 2017 - Accepted: 8 August 2017 - Published: 7 September 2017

\begin{abstract}
Ozone $\left(\mathrm{O}_{3}\right)$ trends and variability from a 28-year (1987-2014) ozonesonde record at Lauder, New Zealand, have been analysed and interpreted using a statistical model and a global chemistry-climate model (CCM). Lauder is a clean rural measurement site often representative of the Southern Hemisphere (SH) mid-latitude background atmosphere. $\mathrm{O}_{3}$ trends over this period at this location are characterised by a significant positive trend below $6 \mathrm{~km}$, a significant negative trend in the tropopause region and the lower stratosphere between 9 and $15 \mathrm{~km}$, and no significant trend in the free troposphere $(6-9 \mathrm{~km})$ and the stratosphere above $15 \mathrm{~km}$. We find that significant positive trends in lower tropospheric ozone are correlated with increasing temperature and decreasing relative humidity at the surface over this period, whereas significant negative trends in the upper troposphere and the lower stratosphere appear to be strongly linked to an upward trend of the tropopause height. Relative humidity and the tropopause height also dominate $\mathrm{O}_{3}$ variability at Lauder in the lower troposphere and the tropopause region, respectively. We perform an attribution of these trends to anthropogenic forcings including $\mathrm{O}_{3}$ precursors, greenhouse gases (GHGs), and $\mathrm{O}_{3}$-depleting substances (ODSs), using CCM simulations. Results indicate that changes in anthropogenic $\mathrm{O}_{3}$ precursors contribute significantly to stratospheric $\mathrm{O}_{3}$ reduction, changes in ODSs contribute significantly to tropospheric $\mathrm{O}_{3}$ reduction, and increased GHGs contribute significantly to stratospheric $\mathrm{O}_{3}$ increases at Lauder. Methane $\left(\mathrm{CH}_{4}\right)$ likely contributes positively to $\mathrm{O}_{3}$ trends in both the troposphere and the stratosphere, but the contribution is not
\end{abstract}

significant at the $95 \%$ confidence level over this period. An extended analysis of CCM results covering 1960-2010 (i.e. starting well before the observations) reveals significant contributions from all forcings to $\mathrm{O}_{3}$ trends at Lauder - i.e. increases in GHGs and the increase in $\mathrm{CH}_{4}$ alone all contribute significantly to $\mathrm{O}_{3}$ increases, net increases in ODSs lead to $\mathrm{O}_{3}$ reduction, and increases in non-methane $\mathrm{O}_{3}$ precursors cause $\mathrm{O}_{3}$ increases in the troposphere and reductions in the stratosphere. This study suggests that a long-term ozonesonde record obtained at a SH mid-latitude background site (corroborated by a surface $\mathrm{O}_{3}$ record at a nearby SH midlatitude site, Baring Head, which also shows a significant positive trend) is a useful indicator for detecting atmospheric composition and climate change associated with human activities.

\section{Introduction}

Ozone $\left(\mathrm{O}_{3}\right)$ is an important trace gas in the Earth's atmosphere, playing a central role in atmospheric chemistry and the radiation budget. Stratospheric $\mathrm{O}_{3}$ prevents harmful UV light from reaching the Earth's surface and is also a source of tropospheric ozone via cross-tropopause exchange. Tropospheric $\mathrm{O}_{3}$ is formed by photochemical production in the presence of nitrogen oxides and volatile organic compounds (VOCs). It controls the atmospheric oxidising capacity through photolysis and subsequent reaction with water vapour to produce the hydroxyl radical $(\mathrm{OH})$. Tropospheric 
$\mathrm{O}_{3}$ is inhomogeneously distributed and highly dependent on the distributions of its precursors and on transport. High levels of surface $\mathrm{O}_{3}$ have adverse effects on human health and vegetation. Since the industrial era, surface $\mathrm{O}_{3}$ in the Northern Hemisphere (NH) has increased substantially (e.g. Volz and Kley, 1988; Thompson, 1992) due to human activities. By contrast, surface $\mathrm{O}_{3}$ in the Southern Hemisphere ( $\mathrm{SH}$ ) is more stable due to limited land and a general lack of precursor emissions. Here, surface $\mathrm{O}_{3}$ is the result of stratospheretroposphere exchange (STE) and methane $\left(\mathrm{CH}_{4}\right)$ oxidation.

In the $\mathrm{SH}$, stratospheric $\mathrm{O}_{3}$ changes, which are dominated by Antarctic ozone depletion, show significant negative trends especially at mid- to high latitudes from the 1980s to the end of the 1990s (WMO, 2011). Reductions in stratospheric halogen due to the implementation of the Montreal Protocol would increase both tropospheric and stratospheric $\mathrm{O}_{3}$; indeed, observations show that stratospheric $\mathrm{O}_{3}$ between 35 and $45 \mathrm{~km}$ has shown no trend since the late 1990s (Figs. 2-5 in WMO, 2014). However, ozone recovery is modulated by climate change. Model simulations show that recovery will occur between 2030 and 2070 (depending on region), but there may be no sustained recovery in the tropical lower stratosphere, where climate change increases tropical upwelling, leading to less time for $\mathrm{O}_{3}$ production and hence reducing $\mathrm{O}_{3}$ in this region (Eyring et al., 2010). As a consequence, future changes of stratospheric $\mathrm{O}_{3}$ will significantly impact tropospheric $\mathrm{O}_{3}$ and potentially air quality (e.g. Zeng et al., 2010).

Understanding past $\mathrm{O}_{3}$ changes and projecting the future $\mathrm{O}_{3}$ evolution are of great importance to assessing future environmental changes. To cover its spatial and temporal variability, an extensive global ozone monitoring network exists measuring total column ozone, vertical profiles, and surface ozone. These measurements cover years to decades. Oltmans et al. (2013) analyse tropospheric $\mathrm{O}_{3}$ trends from a large suite of surface $\mathrm{O}_{3}$ and ozonesonde measurements for the past 2040 years and find that there is no significant overall change in tropospheric $\mathrm{O}_{3}$ in the $\mathrm{NH}$ and tropics; they attribute this lack of growth to controls on $\mathrm{O}_{3}$ precursor emissions after earlier increases in tropospheric $\mathrm{O}_{3}$. However, in the $\mathrm{SH}$ subtropics and mid-latitudes, near-surface $\mathrm{O}_{3}$ exhibits a significant positive trend since the 1980s but there have been no trends in the free and upper troposphere; reasons for this behaviour are not understood.

In this paper, we present the updated ozonesonde record covering 1987-2014 from Lauder, New Zealand $\left(45^{\circ} \mathrm{S}\right.$, $170^{\circ} \mathrm{E} ; 370 \mathrm{~m}$ a.s.l.), a clean rural site that is representative of the SH mid-latitude background atmosphere. Parts of the time series have been shown previously by Oltmans et al. (2006, 2013). Here, we focus on analysing and interpreting the tropospheric and lower stratospheric $\mathrm{O}_{3}$ changes using a simple statistical model and global chemistry-climate model (CCM) simulations, and identify the underlying dynamical and chemical changes that could contribute to the observed $\mathrm{O}_{3}$ trends at this location, which also represent the evolution of background $\mathrm{O}_{3}$ in the $\mathrm{SH}$ mid-latitudes in general. Although we mainly analyse the ozonesonde record at Lauder, the surface $\mathrm{O}_{3}$ record at another $\mathrm{SH}$ mid-latitude site, Baring Head, New Zealand, will also be presented for comparison. We describe the ozonesonde time series, the statistical model used, and the chemistry-climate model simulations in the following section. Results are presented in Sect. 3, and conclusions are drawn in Sect. 4.

\section{Ozone records, statistical method, and chemistry-climate model simulations}

\subsection{Ozone record}

Weekly electrochemical cell (ECC) ozonesondes, launched at Lauder since August 1986, measure profiles of $\mathrm{O}_{3}$, temperature, pressure and winds from the surface to about $35 \mathrm{~km}$. The ozonesondes used are ECC EN-SCI IZ series operating with a $0.5 \%$ buffered potassium iodide (KI) cathode solution (Boyd et al., 1998). Corrections are applied to the ozonesonde values above $200 \mathrm{hPa}$ to account for pump efficiency degradation at low pressures (Bodeker et al., 1998). The integrated $\mathrm{O}_{3}$ profile is compared to the total column of ozone measured by the Dobson spectrophotometer at Lauder; the relative difference is typically less than $5 \%$ (Bodeker et al., 1998). For this analysis, following Oltmans et al. (2013), we calculate vertically averaged $\mathrm{O}_{3}$ mixing ratios for eight layers, namely $0-1.5,1.5-3,3-6,6-9,9-12,12-15$, $15-20$, and $20-25 \mathrm{~km}$. Separate linear trends are then calculated for $\mathrm{O}_{3}$ anomalies at each layer and over the whole period.

\subsection{Statistical method}

We construct a regression model to identify the dominant factors that are associated with $\mathrm{O}_{3}$ variations and trends. The regression model includes nine time-varying forcings, i.e. the solar index (SI), which captures solar variability and is defined by the solar radio flux at F10.7 cm (data source: https:// www.esrl.noaa.gov/psd/data/correlation/solar.data), the multivariate El Niño-Southern Oscillation index (MEI) (https: //www.esrl.noaa.gov/psd/enso/mei/), the Quasi-Biennial Oscillation at 30 and $10 \mathrm{hPa}$, respectively $\left(\mathrm{QBO}_{30}\right.$ and $\left.\mathrm{QBO}_{10}\right)$ (http://www.esrl.noaa.gov/psd/data/climateindices/list/), relative humidity at the surface $\left(\mathrm{RH}_{\text {surf }}\right)$, surface temperature ( $\left.T_{\text {surf }}\right)$, stratospheric temperature averaged over $20-25 \mathrm{~km}$ $\left(T_{\text {strat }}\right)$, tropopause height $\left(\mathrm{HT}_{\text {Trop }}\right)$, and the total chlorine loading $\left(\mathrm{Cl}_{y}\right) . \mathrm{RH}_{\text {surf }}, T_{\text {surf }}$ and $T_{\text {strat }}$ are measured together with $\mathrm{O}_{3}$ by the ozonesondes. We define the tropopause as the minimum altitude where the vertical gradient of the ozone volume mixing ratio (VMR) is greater than $60 \mathrm{ppbv} \mathrm{km}^{-1}$, remains so for a further $200 \mathrm{~m}$, and the $\mathrm{O}_{3}$ mixing ratio is greater than $80 \mathrm{ppbv}$, exceeding $110 \mathrm{ppbv}$ immediately above the tropopause (ozone tropopause; Bethan et al., 1996). The ozone tropopause definition is consistent with the definition 
of the dynamical tropopause based on potential vorticity (e.g. Beekmann et al., 1994). The total chlorine loading at $20 \mathrm{~km}$ over Lauder is taken from a transient CCM simulation assuming the WMO A1 scenario (WMO, 2011). The regressed $\mathrm{O}_{3}$ anomaly is expressed as

$$
\begin{aligned}
& \text { Ozone }(t)=A \times t+a_{1} \times \mathrm{SI}(t)+a_{2} \times \mathrm{MEI}(t) \\
& +a_{3} \times \mathrm{QBO}_{10}(t)+a_{4} \times \mathrm{QBO}_{30}(t)+a_{5} \times \mathrm{RH}_{\text {surf }}(t) \\
& +a_{6} \times T_{\text {surf }}(t)+a_{7} \times T_{\text {strat }}(t)+a_{8} \times \mathrm{HT}_{\text {Trop }}(t) \\
& +a_{9} \times \mathrm{Cl}_{y}(t),
\end{aligned}
$$

where $A \times t$ is the linear component, and $a_{1-9}$ are the regression coefficients for the corresponding regressors. All forcings are standardised but not de-trended. Observations as well as basis functions are monthly mean data.

\subsection{Chemistry-climate model simulations}

We perform and analyse a suite of sensitivity simulations with different model configurations aimed at investigating the factors that potentially contribute to observed $\mathrm{O}_{3}$ trends at Lauder, e.g. $\mathrm{CH}_{4}$ and other $\mathrm{O}_{3}$ precursors, greenhouse gases (GHGs), and ozone-depleting substances (ODSs) over the period of the time series (1987-2014). The model simulations we analyse here are from the National Institute of Water and Atmospheric Research-United Kingdom Chemistry and Aerosols (NIWA-UKCA) model, which comprises a detailed representation of stratospheric and tropospheric chemistry and is optionally run in atmosphere-only mode or coupled to a deep-ocean model. Detailed descriptions of the model are given by Morgenstern et al. (2009, 2017), O'Connor et al. (2014), and Zeng et al. (2015). We only give a brief description of the version used here. The background climate model is an early version of HadGEM3-A (Hewitt et al., 2011) at a horizontal resolution of $3.75^{\circ} \times 2.5^{\circ}$, with 60 levels from the surface to $84 \mathrm{~km}$. Chemistry combines the stratospheric mechanism described by Morgenstern et al. (2009) and the tropospheric mechanism used by Zeng et al. (2008). Eight primary pollutants are emitted at the surface, namely nitrogen oxides $\left(\mathrm{NO}_{x}\right)$, carbon monoxide $(\mathrm{CO})$, formaldehyde $\left(\mathrm{CH}_{2} \mathrm{O}\right)$, ethane $\left(\mathrm{C}_{2} \mathrm{H}_{6}\right)$, acetaldehyde $\left(\mathrm{CH}_{3} \mathrm{CHO}\right)$, propane $\left(\mathrm{C}_{3} \mathrm{H}_{8}\right)$, acetone $\left(\mathrm{CH}_{3} \mathrm{COCH}_{3}\right)$, and isoprene $\left(\mathrm{C}_{5} \mathrm{H}_{8}\right)$. We assume uniform, constant lower boundary conditions for nitrous oxide $\left(\mathrm{N}_{2} \mathrm{O}\right), \mathrm{CH}_{4}$, hydrogen $\left(\mathrm{H}_{2}\right)$, and organic halogen compounds. Chlorine and bromine source gases are lumped, and we only explicitly model $\mathrm{CFCl}_{3}, \mathrm{CF}_{2} \mathrm{Cl}_{2}, \mathrm{CH}_{3} \mathrm{Br}, \mathrm{CH}_{2} \mathrm{Br}_{2}$, and $\mathrm{CHBr}_{3}$ here. Aerosol and aerosol precursor emissions are included. Lightning emissions of $\mathrm{NO}_{x}$ are parameterised as a function of cloud top height that is linked to convection in the model (Price and Rind, 1992, 1994). The model uses the FAST-JX interactive photolysis scheme (Neu et al., 2007; Telford et al., 2013) with a correction added above $60 \mathrm{~km}$ for photolysis occurring at wavelengths shorter than $177 \mathrm{~nm}$ (Lary and Pyle, 1991).
All simulations used in this study are listed in Table 1; they are part of the Chemistry Climate Model Initiative (CCMI) model simulations (Eyring et al., 2013; Morgenstern et al., 2017). The model data can be downloaded from the British Atmospheric Data Centre (BADC) (http://blogs.reading.ac. $\mathrm{uk} / \mathrm{ccmi} /$ badc-data-access). We keep the experiment identifications as defined by Eyring et al. (2013) and Morgenstern et al. (2017) for CCMI. REF-C1 is a hindcast experiment using prescribed observed monthly mean sea surface temperatures (SSTs) and sea ice (HadISST; Rayner et al., 2003) over the period of 1960-2010. Other forcings, e.g. GHGs, ODSs, and aerosol and aerosol precursor emissions, follow state-of-knowledge historical evolutions from 1960 to 2010 (Morgenstern et al., 2017). The anthropogenic emissions of $\mathrm{O}_{3}$ precursors are inter-annually varying following the MACCity scenario from 1960 to 2010 (Granier et al., 2011), and biogenic emissions are prescribed following the MEGAN2.1 (Guenther et al., 2012) dataset with no inter-annual variation. $\mathrm{CH}_{4}$ mixing ratios are prescribed at the surface. In this setup, chemistry is interactive, in that calculated $\mathrm{O}_{3}$ and $\mathrm{CH}_{4}$ are fed into the radiation scheme. We consider REF-C1 to be the state-of-knowledge experiment of the evolution of chemical composition from 1960 to 2010. We also performed a simulation with non-methane $\mathrm{O}_{3}$ precursor emissions fixed at the 1960 level (SEN-C1-fEMIS) to assess the impact of increases in these emissions since 1960 . Here we analyse the results between 1987 and 2010 to coincide with the Lauder ozonesonde measurements. In addition, we specify a stratospheric $\mathrm{O}_{3}$ tracer $\left(\mathrm{O}_{3} \mathrm{~S}\right)$ to examine the impact of STE on tropospheric $\mathrm{O}_{3}$ in experiment REF-C1. $\mathrm{O}_{3} \mathrm{~S}$ is defined as having the same chemical destruction as the "normal" chemical $\mathrm{O}_{3}$ tracer but no chemical production in the troposphere in order to account for the $\mathrm{O}_{3}$ that is originated from the stratosphere.

The second set of simulations is used to attribute $\mathrm{O}_{3}$ changes to ODSs and GHGs and listed in Table 1. These simulations are carried out using the coupled atmosphere-ocean configuration. REF-C2 is the reference simulation covering the period of 1960-2100 and follows the WMO (2011) A1 scenario for ODSs and Representative Concentration Pathway (RCP) 6.0 (Meinshausen et al., 2011) for other GHGs, tropospheric $\mathrm{O}_{3}$ precursors, and aerosol and aerosol precursor emissions. For anthropogenic $\mathrm{O}_{3}$ precursor emissions, we use MACCity emissions until 2000, followed by RCP 6.0 emission, as recommended for CCMI simulations. Unfortunately, there is a discontinuity in $\mathrm{NO}_{x}$ emissions when this transition occurs (Morgenstern et al., 2017), which will impact the $\mathrm{O}_{3}$ trend calculation. The three sensitivity simulations (SEN-C2-fODS, SEN-C2-fGHG, and SEN-C2-fCH4) differ from the REF-C2 simulation in that ODSs, GHGs, and $\mathrm{CH}_{4}$ are fixed at their 1960 levels. The discontinuity in $\mathrm{NO}_{x}$ emissions exists in all three sensitivity simulations; therefore, we anticipate that its effect will be similar across all simulations. We analyse results from 1987 to 2014, which cover the Lauder ozonesonde time series. The time evolutions of $\mathrm{CH}_{4}$, 
Table 1. Chemistry-Climate Model Initiative (CCMI) simulations performed by NIWA-UKCA, used in this study.

\begin{tabular}{|c|c|c|c|c|c|c|}
\hline Simulation & Period & SSTs/sea ice & $\mathrm{O}_{3}$ precursor emissions* & $\mathrm{CH}_{4}$ & GHGs* & ODSs \\
\hline REF-C1 & 1960-2010 & HadISST & MACCity (1960-2010) & RCP 6.0 & RCP 6.0 & WMO (2014) A1 \\
\hline SEN-C1-fEMIS & 1960-2010 & HadISST & Fixed at 1960 & RCP 6.0 & RCP 6.0 & WMO (2014) A1 \\
\hline REF-C2 & $1960-2100$ & Interactive & $\begin{array}{l}\text { MACCity (1960-2000) and } \\
\text { RCP } 6.0(2000-2100)\end{array}$ & RCP 6.0 & RCP 6.0 & WMO (2014) A1 \\
\hline SEN-C2-fGHG & $1960-2100$ & Interactive & $\begin{array}{l}\text { MACCity (1960-2000) and } \\
\text { RCP } 6.0(2000-2100)\end{array}$ & Fixed at 1960 & Fixed at 1960 & WMO (2014) A1 \\
\hline SEN-C2--fCH & $1960-2100$ & Interactive & $\begin{array}{l}\text { MACCity (1960-2000) and } \\
\text { RCP } 6.0(2000-2100)\end{array}$ & Fixed at 1960 & RCP 6.0 & WMO (2014) A1 \\
\hline SEN-C2-fODS & $1960-2100$ & Interactive & $\begin{array}{l}\text { MACCity (1960-2000) and } \\
\text { RCP } 6.0(2000-2100)\end{array}$ & RCP 6.0 & RCP 6.0 & Fixed at 1960 \\
\hline
\end{tabular}

* Excluding $\mathrm{CH}_{4}$.
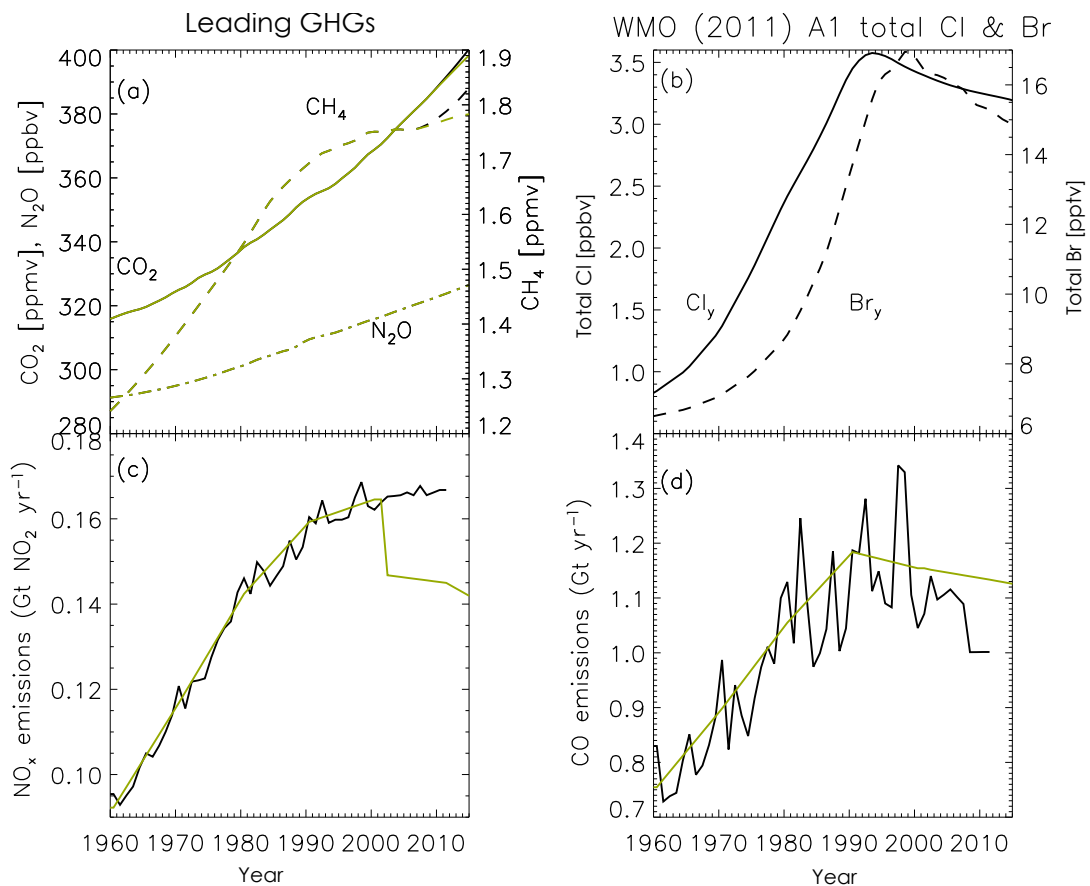

Figure 1. Time evolution of anthropogenic forcings used in CCMI simulations: (a) greenhouse gases (GHGs) volume mixing ratios, (b) total organic chlorine and bromine volume mixing ratios, (c) nitrogen oxide emissions $\left(\mathrm{NO}_{x}\right)$, and (d) carbon monoxide emissions $(\mathrm{CO})$. Black lines denote forcings used in REF-C1, and lime lines for REF-C2. Note the discontinuity in $\mathrm{NO}_{x}$ emissions (c) mentioned in the text.

$\mathrm{CO}_{2}, \mathrm{~N}_{2} \mathrm{O}, \mathrm{Cl}_{y}$, and $\mathrm{Br}_{y}$, and the surface emissions of $\mathrm{NO}_{x}$ and $\mathrm{CO}$ are displayed in Fig. 1.

\section{Observed ozone variabilities and trends at Southern Hemisphere mid-latitudes}

\subsection{Ozone variability}

Deseasonalised $\mathrm{O}_{3}$ anomalies, based on observed $\mathrm{O}_{3}$ at Lauder, at the eight layers from the surface to the lower stratosphere and the respective regressed $\mathrm{O}_{3}$ anomalies are shown in Fig. 2. The observed monthly mean data was gener- ated by performing a linear regression through the observed $\mathrm{O}_{3}$ sonde data taken during each month (normally three or four measurements) in order to define a representative point in the middle of the month. The regressed $\mathrm{O}_{3}$ values are generated based on the monthly mean observed data via the multi-linear regression expressed by Eq. (1). $\mathrm{O}_{3}$ anomalies shown in Fig. 2 and in subsequent figures, where indicated in respective figure captions, are smoothed with a 13-month filter for the purpose of display. Figure 2 shows that large interannual variations exist in the observed $\mathrm{O}_{3}$ anomalies, and the $\mathrm{O}_{3}$ regression captures much of the variability in the stratosphere but is less accurate at capturing variations 

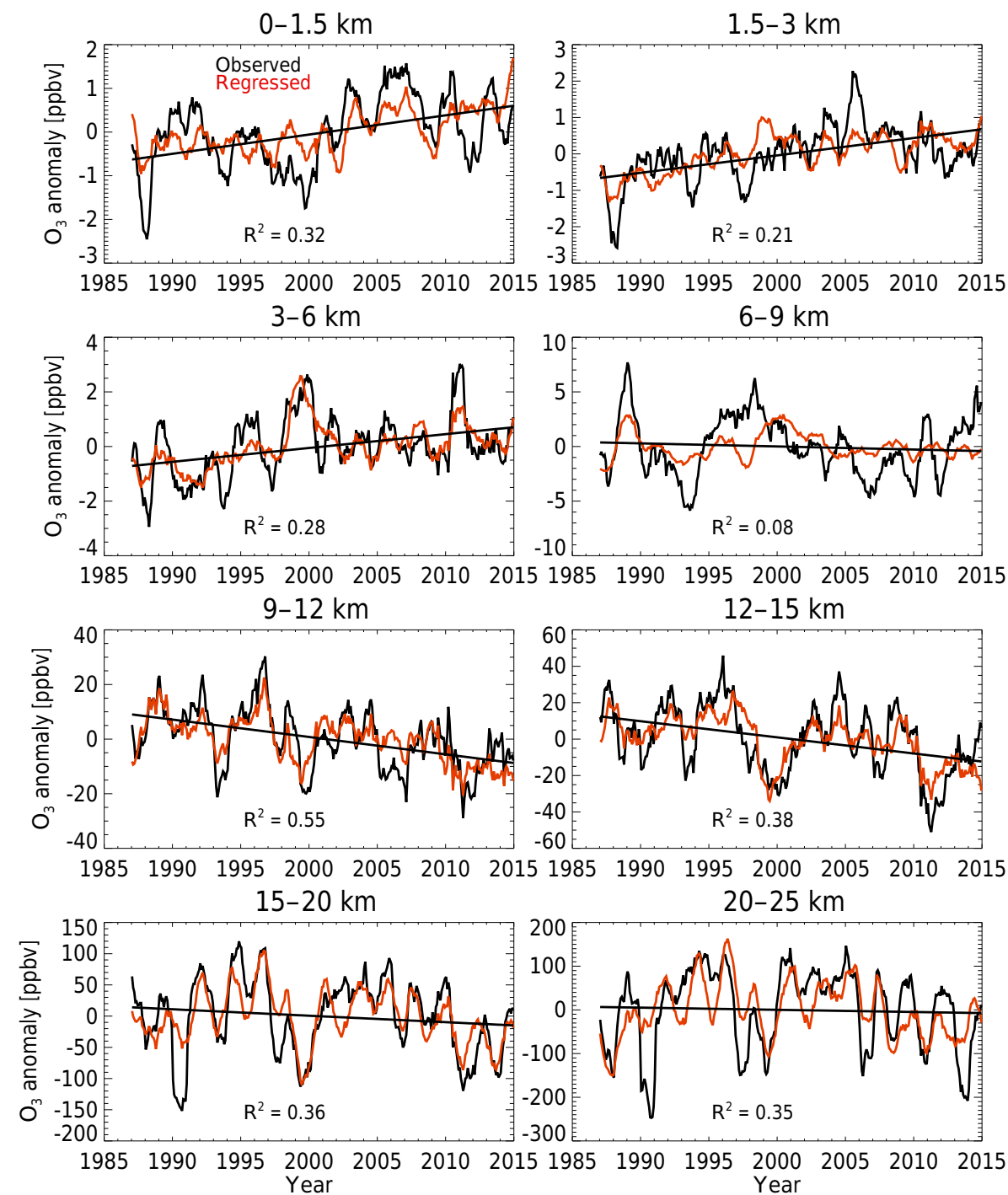

Figure 2. Vertically resolved observed ozone anomalies (black curves), linear trends (black lines), and regressed $\mathrm{O}_{3}$ anomalies (red curves) at Lauder (1987-2014). $R^{2}$ is the coefficient of determination of multi-variant regression function at each layer. The $\mathrm{O}_{3}$ anomalies shown are smoothed using a 13-month filter based on monthly mean data. Linear trends are calculated from the monthly mean $\mathrm{O}_{3}$ anomalies.

Table 2. Coefficient of determination, $R^{2}$, and dominant contributors to the regression, based on coefficients of determination of individual regression functions $\left(r^{2}\right)$, resolved by altitude.

\begin{tabular}{lllll}
\hline Altitudes & $R^{2}$ & \multicolumn{2}{c}{ Dominant regression functions (measured by $\left.r^{2}\right)$} \\
\hline $0-1.5 \mathrm{~km}$ & 0.32 & Relative humidity $(0.25)$ & Surface temperature $(0.13)$ & \\
$1.5-3 \mathrm{~km}$ & 0.21 & Tropopause height $(0.10)$ & Surface temperature $(0.09)$ & Relative humidity $(0.05)$ \\
$3-6 \mathrm{~km}$ & 0.28 & Surface temperature $(0.15)$ & Tropopause height $(0.11)$ & Stratospheric temperature $(0.08)$ \\
$6-9 \mathrm{~km}$ & 0.08 & ENSO (0.02) & Tropopause height $(0.01)$ & \\
$9-12 \mathrm{~km}$ & 0.55 & Tropopause height $(0.50)$ & Surface temperature $(0.09)$ & Stratospheric temperature (0.07) \\
$12-15 \mathrm{~km}$ & 0.38 & Tropopause height $(0.29)$ & Surface temperature $(0.14)$ & Stratospheric temperature (0.06) \\
$15-20 \mathrm{~km}$ & 0.36 & Tropopause height $(0.14)$ & Surface temperature $(0.11)$ & QBO at 30 hPa $(0.10)$ \\
$20-25 \mathrm{~km}$ & 0.35 & Stratospheric temperature (0.18) & QBO at 30 hPa (0.09) & Surface temperature $(0.03)$ \\
\hline
\end{tabular}



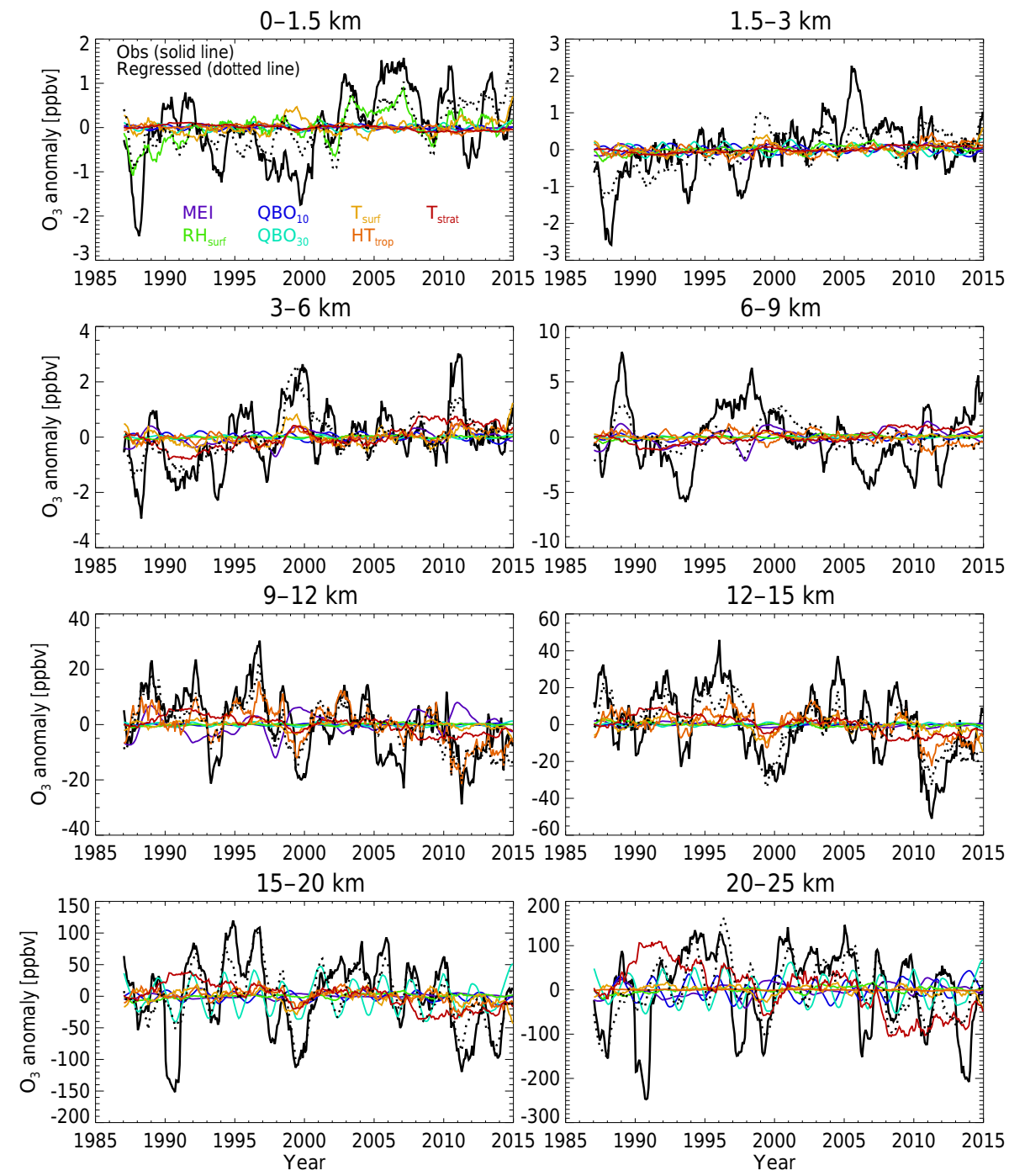

Figure 3. Ozone anomalies and contributions of individual regression functions at Lauder. $\mathrm{O}_{3}$ anomalies are monthly mean but are smoothed using a 13-month filter for display. Colour keys for regressors are shown in the top-left panel.

in tropospheric $\mathrm{O}_{3}$ in general (Fig. 2). The amount of $\mathrm{O}_{3}$ variance explained by the regression is given by the multiple regression coefficient of determination, $R^{2}$ (Fig. 2 and Table 2), which shows that in the layer of $9-12 \mathrm{~km}$, the regression achieves the highest $R^{2}$ value of 0.55 , followed by the lower stratospheric layers $(12-20 \mathrm{~km})$ with $R^{2}$ values of 0.38 and 0.36 , respectively. The surface layer has a better fit $\left(R^{2}=0.32\right)$ than the layers in the free tropospheric layers which have lower $R^{2}$ values of $0.08-0.28$.

We show contributions of individual regression functions to the regressed $\mathrm{O}_{3}$ anomalies (Fig. 3) and identify major contributing variables measured by the coefficient determination of individual regression functions, $r^{2}$ (Table 2). At the surface, the $\mathrm{O}_{3}$ anomaly is reasonably well captured by the regression which is dominated by relative humidity (Fig. 3); this may indicate that stratospheric intru- sions play a significant role in controlling surface $\mathrm{O}_{3}$ variations at Lauder, as relative humidity is considered an effective indicator of such intrusions (e.g. Cristofanelli et al., 2006; Stohl et al., 2000). Around and immediately above the tropopause (i.e. $9-15 \mathrm{~km}$ ), the $\mathrm{O}_{3}$ anomalies largely follow the tropopause height (Fig. 3), which reflects that $\mathrm{O}_{3}$ in this region is mainly controlled by changes in dynamics. Indeed, change in tropopause height dominates the regression function at the layer of $9-12 \mathrm{~km}\left(r^{2}=0.50\right)$, and such dynamical change also influences $\mathrm{O}_{3}$ variability in the troposphere and the lower stratosphere (see Table 2). In the free troposphere, between 1.5 and $9 \mathrm{~km}, \mathrm{O}_{3}$ variations are mostly driven by a number of factors, including tropopause height, relative humidity, surface temperature, and the MEI, with surface temperature and relative humidity playing a dominant role in the lower troposphere. There is a notable influence of El Niño- 

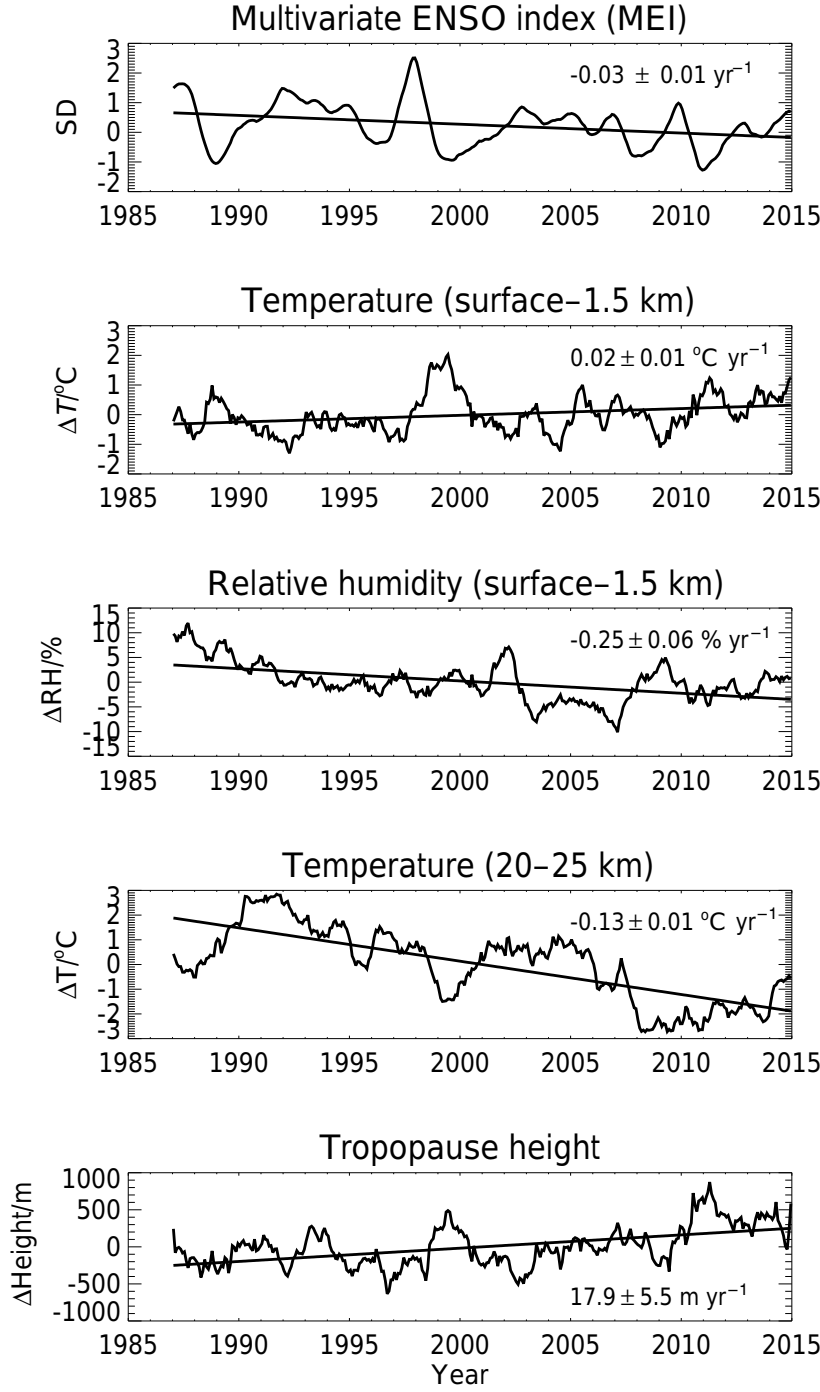

Figure 4. Time series of dominant climate/meteorological variables, co-measured with $\mathrm{O}_{3}$ at Lauder, with the exception of the multivariate ENSO index (MEI). Anomalies are monthly mean but are smoothed using a 13-month filter for display. Linear trends for all variables are noted in the figure.

Southern Oscillation (ENSO) on ozone variations in the region between 3 and $9 \mathrm{~km}$ (Fig. 3). In the lower stratosphere, stratospheric temperature and the QBO at $30 \mathrm{hPa}$ show increasing dominance in contributing to $\mathrm{O}_{3}$ variability (Table 2).

Time series of some of the meteorological and climate variables used in the regression are shown in Fig. 4. Except for the MEI time series, all other variables are measured jointly with $\mathrm{O}_{3}$ at Lauder. In order to directly assess the relationship between these variables and $\mathrm{O}_{3}$ variability, we calculate correlation coefficients $(r)$ of these variables with $\mathrm{O}_{3}$ anomalies for each layer (see Table 3). This analysis shows clearly that $\mathrm{RH}_{\text {surf }}$ exhibits a strong anti-correlation with the $\mathrm{O}_{3}$ anomalies close to the surface $(r=-0.50)$, and the correlation reduces at higher altitudes, implying a role for deep stratospheric intrusion in near-surface $\mathrm{O}_{3}$ variability as mentioned above. Surface temperature anomalies and $\mathrm{O}_{3}$ anomalies in the troposphere are positively correlated, but are anti-correlated in the stratosphere. Likewise, stratospheric temperature anomalies and stratospheric $\mathrm{O}_{3}$ anomalies are correlated. Tropopause height and $\mathrm{O}_{3}$ are anti-correlated in the stratosphere and are correlated in the troposphere, and the strongest anti-correlation occurs in the tropopause region $(9-12 \mathrm{~km} ; r=-0.71)$ and immediately above the tropopause $(12-15 \mathrm{~km} ; r=-0.57)$. Moderately high correlation coefficients are calculated between tropopause height and $\mathrm{O}_{3}$ anomalies in the free troposphere and in the lower stratosphere, indicating the predominant impact of dynamical changes on $\mathrm{O}_{3}$ over Lauder. There are rather weak correlations between ENSO (expressed as MEI) and $\mathrm{O}_{3}$ anomalies, with the largest influence from ENSO in the free troposphere at this mid-latitude location. QBO at $30 \mathrm{hPa}$ is mostly anti-correlated with ozone anomalies in the stratosphere.

Significant correlations exist between some regression functions, e.g. surface temperature and surface relative humidity $(r=-0.41)$, tropopause height and surface temperature $(r=0.50)$, tropopause height and stratospheric temperature $(r=-0.28)$, and surface temperature and stratospheric temperature $(r=-0.23)$; therefore, it is expected that increased uncertainties exist in the combined use of these variables in regression. In this study, however, variables with dominant contributions to the regression function (listed in Table 2) are all significant at the $95 \%$ confidence level.

\subsection{Ozone trends}

The linear trends in observed deseasonalised $\mathrm{O}_{3}$ anomalies calculated for each layer are listed in Table 4, and are also shown in Fig. 2. Significant positive linear trends $\left(0.04\right.$ ppbv year $\left.^{-1}\right)$ are found from the surface up to $6 \mathrm{~km}$ over the 28-year period (1987 to 2014). No significant trend is calculated for $6-9 \mathrm{~km}$. Above $9 \mathrm{~km}$, trends become significantly negative, but with an insignificant negative trend obtained for $20-25 \mathrm{~km}$. To examine whether there are any synergies between the trends in $\mathrm{O}_{3}$ and the dominant meteorological and climate variables, the linear trends of the meteorological and climate variables over this period are also calculated and are shown in Fig. 4, which clearly shows that there are significant linear trends in MEI, $\mathrm{RH}_{\text {surf }}$, surface and stratospheric temperatures, and tropopause height anomalies over the period of 1987 to 2014, with significant positive trends in surface temperature $\left(0.02 \pm 0.01 \mathrm{~K} \mathrm{year}^{-1}\right)$, and the tropopause height $\left(17.9 \pm 5.5 \mathrm{myear}^{-1}\right)$, and significant negative trends in $\mathrm{RH}_{\text {surf }}\left(-0.25 \pm 0.06 \%\right.$ year $\left.^{-1}\right)$, stratospheric temperatures $\left(-0.13 \pm 0.01 \mathrm{Kyear}^{-1}\right)$, and MEI $\left(-0.03 \pm 0.01\right.$ year $\left.^{-1}\right)$ (Fig. 4). Significant trends in these variables may indicate some shifts in climate variability, and climate change, which are mainly induced by increasing GHGs (e.g. Mitchell et al., 1995; Santer et al., 1996). 
Table 3. Correlation coefficients between $\mathrm{O}_{3}$ anomalies and climate/meteorological variables at each layer.

\begin{tabular}{lrrrrrr}
\hline Ozone layers & $\mathrm{RH}_{\text {surf }}$ & $T_{\text {surf }}$ & $T_{\text {strat }}$ & MEI & $\mathrm{QBO}_{30}$ & $\mathrm{HT}_{\text {Trop }}$ \\
\hline $\mathrm{O}_{3}(0-1.5 \mathrm{~km})$ & -0.50 & 0.38 & & & -0.12 & 0.16 \\
$\mathrm{O}_{3}(1.5-3 \mathrm{~km})$ & -0.28 & 0.35 & -0.17 & -0.11 & & 0.34 \\
$\mathrm{O}_{3}(3-6 \mathrm{~km})$ & -0.20 & 0.42 & -0.29 & -0.18 & & 0.38 \\
$\mathrm{O}_{3}(6-9 \mathrm{~km})$ & & & & -0.15 & & -0.14 \\
$\mathrm{O}_{3}(9-12 \mathrm{~km})$ & 0.21 & -0.44 & 0.31 & & & -0.71 \\
$\mathrm{O}_{3}(12-15 \mathrm{~km})$ & 0.23 & -0.45 & 0.27 & 0.13 & & -0.57 \\
$\mathrm{O}_{3}(15-20 \mathrm{~km})$ & & -0.36 & 0.32 & 0.10 & -0.32 & -0.41 \\
$\mathrm{O}_{3}(20-25 \mathrm{~km})$ & & -0.18 & 0.43 & & -0.31 & -0.18 \\
\hline
\end{tabular}

Table 4. Observed and simulated trends in $\mathrm{O}_{3}$ and $\mathrm{O}_{3} \mathrm{~S}$ anomalies ( \pm 1 standard error) at Lauder, over the periods of 1987-2010 and 19872014. Units are ppbv year ${ }^{-1}$.

\begin{tabular}{lrrrrr}
\hline Altitude $(\mathrm{km})$ & $\begin{array}{r}\mathrm{Observed}_{3} \\
1987-2010\end{array}$ & $\begin{array}{r}\mathrm{Observed}_{3} \\
1987-2014\end{array}$ & $\begin{array}{r}\text { REF-C1 } \mathrm{O}_{3} \\
1987-2010\end{array}$ & $\begin{array}{r}\text { REF-C2 } \mathrm{O}_{3} \\
1987-2014\end{array}$ & $\begin{array}{r}\text { REF-C1 O} \\
1987-2010\end{array}$ \\
\hline $0-1.5$ & $0.06 \pm 0.02$ & $0.04 \pm 0.01$ & $0.00 \pm 0.01$ & $-0.05 \pm 0.01$ & $-0.02 \pm 0.00$ \\
$1.5-3$ & $0.08 \pm 0.02$ & $0.04 \pm 0.01$ & $0.01 \pm 0.01$ & $-0.06 \pm 0.01$ & $-0.02 \pm 0.01$ \\
$3-6$ & $0.06 \pm 0.03$ & $0.05 \pm 0.02$ & $0.02 \pm 0.02$ & $-0.07 \pm 0.01$ & $0.00 \pm 0.01$ \\
$6-9$ & $-0.09 \pm 0.05$ & $-0.01 \pm 0.05$ & $-0.01 \pm 0.02$ & $-0.10 \pm 0.02$ & $-0.04 \pm 0.02$ \\
$9-12$ & $-0.55 \pm 0.27$ & $-0.62 \pm 0.21$ & $-0.39 \pm 0.12$ & $-0.26 \pm 0.07$ & $-0.47 \pm 0.13$ \\
$12-15$ & $-0.53 \pm 0.44$ & $-0.90 \pm 0.35$ & $-1.18 \pm 0.32$ & $-0.51 \pm 0.23$ & $-1.19 \pm 0.32$ \\
$15-20$ & $0.89 \pm 1.12$ & $-1.01 \pm 0.88$ & $-4.19 \pm 0.73$ & $-1.00 \pm 0.56$ & $-4.19 \pm 0.73$ \\
$20-25$ & $1.46 \pm 1.61$ & $-0.50 \pm 1.28$ & $-4.46 \pm 0.95$ & $0.20 \pm 0.69$ & $-4.56 \pm 0.96$ \\
\hline
\end{tabular}

Indeed, the increase in surface temperature and the large decrease in stratospheric temperature are the result of a modified radiation balance. Temperature changes in turn result in dynamical changes, such as changes in tropopause height as shown in Fig. 4, likely due to stratospheric cooling. $\mathrm{RH}_{\text {surf }}$ shows a significantly strong negative trend; this is typically linked to increased deep stratospheric intrusion. MEI shows a moderate negative trend which can be explained by a shift in climate variability. We also calculate $\mathrm{O}_{3}$ trends over the period of 1987 to 2010 and obtain slightly larger significant positive $\mathrm{O}_{3}$ trends in the troposphere (Table 4) than those from the period of 1987 to 2014.

Our trend calculation is in broad agreement with Oltmans et al. (2013), who calculated a trend of 0.15 ppbvyear $^{-1}$ in $\mathrm{O}_{3}$ from the surface to the free troposphere over the period of 1986-2010, and no significant trend above $500 \mathrm{hPa}$, although they did not include $\mathrm{O}_{3}$ trends in the stratosphere in their study. Oltmans et al. (2013) did not elaborate on what exactly drives the significant positive trends in the lower troposphere at the SH mid-latitude site Lauder. There is no significant trend in the upper troposphere. They suggested that such a pattern in tropospheric $\mathrm{O}_{3}$ trends does not reflect a possible increase in STE, as increasing STE would lead to an increase in $\mathrm{O}_{3}$ in the upper and free troposphere. From our analysis based on regression/correlation, the deep stratospheric intrusions may play a role in the lower tropospheric $\mathrm{O}_{3}$ trends, reflected in the significant negative trend in relative humidity over the period of 1987 to 2014 (Fig. 4). However, we cannot derive simple and direct links between changes in relative humidity, deep stratospheric intrusions, and the observed trends in near-surface $\mathrm{O}_{3}$. In the tropopause region, the change in tropopause height clearly drives the $\mathrm{O}_{3}$ variation and trend i.e. significant upward trends in tropopause height imply significant negative $\mathrm{O}_{3}$ trends between 9 and $15 \mathrm{~km}$ (Figs. 2 and 4). In the stratosphere above $15 \mathrm{~km}$, negative $\mathrm{O}_{3}$ trends become weaker and are not significant at the $95 \%$ confidence level. Long-term changes in $\mathrm{O}_{3}$ in this region are influenced by changes in dynamics (which are reflected in changes in stratospheric temperatures linked to $\mathrm{O}_{3}$ changes), and $\mathrm{O}_{3}$ depletion/recovery that is governed by changes in $\mathrm{O}_{3}$-depleting substances; such changes seem to have cancelled out the decrease in $\mathrm{O}_{3}$ resulting from the tropopause height increase in this region. Similarly, the insignificant trend in $\mathrm{O}_{3}$ between 6 and $9 \mathrm{~km}$ may be the result of cancellations between the increase in $\mathrm{O}_{3}$ in the lower troposphere and the decrease in $\mathrm{O}_{3}$ in the tropopause region. In Sect. 4, we analyse a set of sensitivity simulations designed to assess the contributions from some anthropogenic forcings (ODSs, GHGs, and $\mathrm{O}_{3}$ precursors), which are known to have caused substantial changes in recent decades to $\mathrm{O}_{3}$ trends.

\subsection{Baring Head surface $\mathrm{O}_{3}$}

In addition to the ozonesonde record at Lauder, we examine the surface $\mathrm{O}_{3}$ time series from Baring $\mathrm{Head}\left(41.4^{\circ} \mathrm{S}\right.$, 


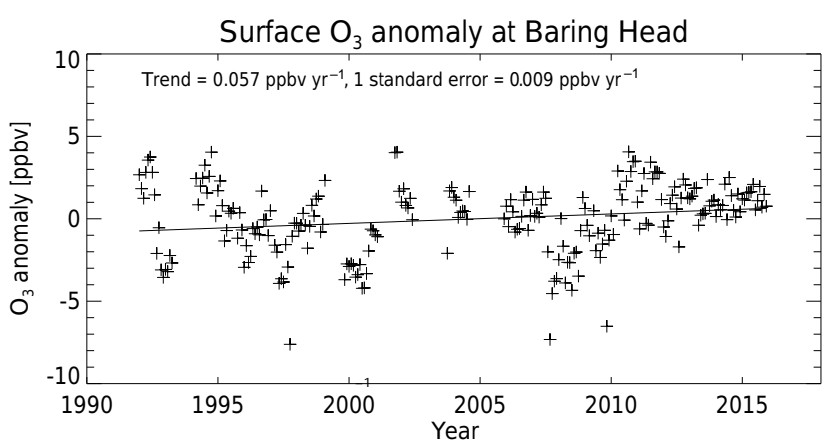

Figure 5. Observed monthly mean surface $\mathrm{O}_{3}$ anomaly and the corresponding linear trend at Baring Head (1994-2015).

$174.9^{\circ} \mathrm{E} ; 85 \mathrm{~m}$ ), which is also a SH mid-latitude background station located in central New Zealand. In southerly wind situations Baring Head, a coastal site, is exposed to clean marine air. The surface $\mathrm{O}_{3}$ measurements at Baring Head started in 1991; the record is largely continuous except for some missing data in 2005. The surface $\mathrm{O}_{3}$ measurements have been made using ultraviolet (UV) photometric ozone analysers (Dasibi model 1003-PC from 1991-2004, and Thermo Electric Corporation TEI49i from 1995), with air drawn from $5 \mathrm{~m}$ above the ground through a dedicated Teflon tube with a $0.5 \mu \mathrm{m}$ Teflon filter on the inlet to exclude aerosols. Hourly data from 1992 to 2015 are used to calculated the surface $\mathrm{O}_{3}$ anomaly and the trend. The data are also deseasonalised.

Shown in Fig. 5, a significant positive trend is calculated in surface $\mathrm{O}_{3}\left(0.057\right.$ ppbv year $\left.^{-1}\right)$ at Baring Head, which is similar to the trend found at Lauder $\left(0.04-0.06 \mathrm{ppbv}_{\text {year }}{ }^{-1}\right)$, but the positive trend calculated from near-surface ozonesonde data at Lauder exhibits a much larger uncertainty range. The significant positive trend in surface $\mathrm{O}_{3}$ at Baring Head, together with the significant positive trends in Cape Grim and Cape Point surface $\mathrm{O}_{3}$ calculated by Oltmans et al. (2013), confirms that the positive surface $\mathrm{O}_{3}$ trends in the $\mathrm{SH}$ midlatitudes are robust. The insignificant positive trend in surface $\mathrm{O}_{3}$ at Baring Head calculated by Oltmans et al. (2013) over the period of 1991-2010 is due to the shorter data record compared to the record used here.

\section{Attribution of ozone trends using chemistry-climate model simulations}

\subsection{Modelled ozone trends at Lauder}

In order to attribute the observed $\mathrm{O}_{3}$ trends at Lauder in a more quantitative way, we compare the observations to model results. Although the model has a relatively coarse resolution, the measurement site is representative of SH midlatitudes, which are characterised by relatively large-scale variability in $\mathrm{O}_{3}$. Firstly, we show in Fig. 6 monthly mean $\mathrm{O}_{3}$ volume mixing ratios at all eight layers, for both REF-C1 and REF-C2 simulations (in the case of REF-C1, the run ends in 2010; therefore, we use the period of 1987-2010). The model data are interpolated to the vertical resolution of the ozonesonde, before being grouped into the same eight layers as defined before. Overall, the model captures the magnitude and variability of $\mathrm{O}_{3}$ well, albeit with the overestimation of some observed peak values, mainly at the surface and in the stratosphere. The model is capable of reproducing the observed $\mathrm{O}_{3}$ seasonal cycle in general but underestimates the $\mathrm{O}_{3}$ seasonal cycle in the free troposphere at this location. Comparing the two model experiments, i.e. REF$\mathrm{C} 1$ and REF-C2, we find that $\mathrm{O}_{3}$ values in the REF-C1 experiment are generally larger than those in REF-C2, with the largest differences in the free troposphere at $3-6 \mathrm{~km}$. Such differences might be due to the dynamical differences arising from differences in sea surface temperatures between the two experiments. We calculate the linear trends of $\mathrm{O}_{3}$ in both experiments, as well as in the sensitivity experiments. The results are discussed in the following sections.

\subsection{REF-C1 simulation and the impact from $\mathrm{O}_{3}$ precursor emissions and the stratosphere}

Layer-resolved $\mathrm{O}_{3}$ anomalies and their trends from REF-C1 and SEN-C1-fEMIS are displayed in Fig. 7 for the period of 1987-2010, together with the observed anomalies for the same period. Modelled $\mathrm{O}_{3}$ anomalies are based on monthly mean output from the CCMs, smoothed using a 13-month filter. Trends are calculated based on monthly mean data without any smoothing. The same applies for all modelled $\mathrm{O}_{3}$ anomalies shown in respective figures. In addition, the anomalies in the stratospheric $\mathrm{O}_{3}$ tracer $\mathrm{O}_{3} \mathrm{~S}$ are also displayed in the same plot. The modelled trends of $\mathrm{O}_{3}$ and $\mathrm{O}_{3} \mathrm{~S}$ are summarised in Table 4. Overall, the REF-C1 simulation captures some basic observed variability but misses some large anomaly features, for example the very negative $\mathrm{O}_{3}$ anomalies near the surface in the year 2000, and at the beginning of the record (1987-1988). There are large observed variations in the upper troposphere $(6-9 \mathrm{~km})$ that the model fails to reproduce. The observed variabilities of $\mathrm{O}_{3}$ around the tropopause and in the lower stratosphere are well captured by the model. The modelled trends match well with the observed trend in the tropopause region and in the upper troposphere $(6-12 \mathrm{~km})$, but the model cannot reproduce the observed significant positive $\mathrm{O}_{3}$ trends below $6 \mathrm{~km}$. The model simulation also produces a positive, but smaller than observed, trend in tropopause height $\left(7.6 \pm 3.7 \mathrm{~m} \mathrm{year}^{-1}\right.$ over 1987-2010. Above $15 \mathrm{~km}$ in the stratosphere, large positive anomalies from the model at the beginning of the record are opposite in sign to the observed negative anomalies and lead to the significant negative trends calculated in the REF-C1 simulation (excluding the first few years of data, e.g. 19871989 , the model will produce a weaker insignificant negative trend at $20-25 \mathrm{~km}$ ). In contrast, observed $\mathrm{O}_{3}$ trends in the stratosphere are generally insignificant. For comparing to 

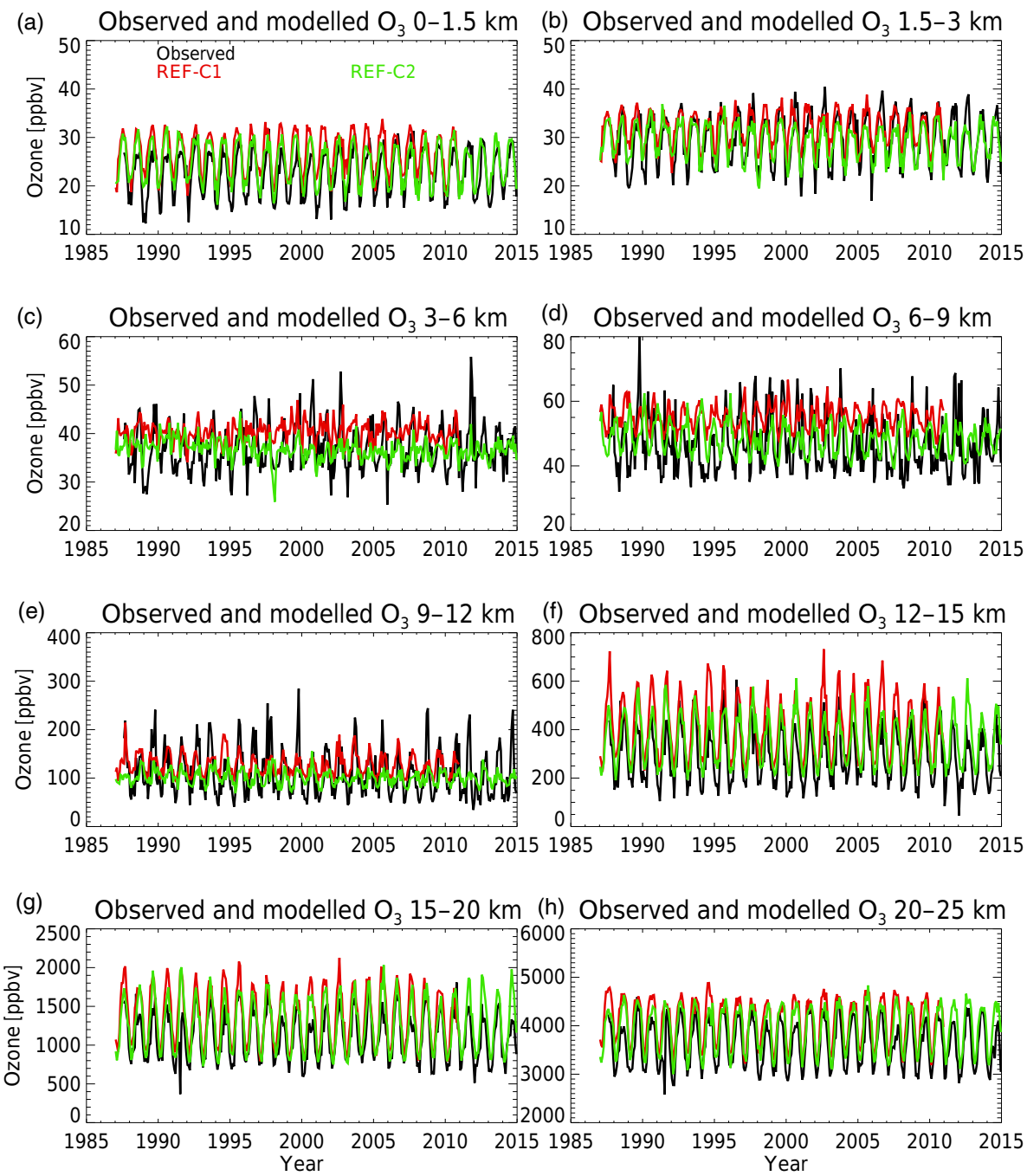

Figure 6. Observed (black) and modelled monthly mean $\mathrm{O}_{3}$ time series, from REF-C1 (red) and REF-C2 (green), respectively, at Lauder over 1987-2014. The REF-C1 simulation ends in year 2010.

observations at a specific location, we expect that chemical transport models (CTMs) or CCMs with specified dynamics (CCM-SD) would be more accurate in capturing the $\mathrm{O}_{3}$ variability and other dynamical variables than free-running CCMs; this has been demonstrated in previous studies (e.g. Hardiman et al., 2017). This could have implications for projecting long-term future $\mathrm{O}_{3}$ trends using free-running CCMs. Therefore, careful evaluations of free-running CCMs are needed. However, Hardiman et al. (2017) also find that tropical upwelling and the stratospheric meridional circulation are difficult to constrain and are worse in the nudged simulations than in the free-running simulations. Here, we aim to attribute observed $\mathrm{O}_{3}$ trends to various chemical and dynamical processes, and we consider that free-running CCMs are the more suitable models to be used in such study.

We consider the REF-C1 simulation to be a representation of the realistic $\mathrm{O}_{3}$ evolution, driven by observed SSTs and well-understood historic anthropogenic forcings such as GHGs and ODSs, including $\mathrm{CH}_{4}$, which affects $\mathrm{O}_{3}$ both chemically and as a GHG. However, anthropogenic nonmethane $\mathrm{O}_{3}$ precursors have relatively large uncertainties, due to their very heterogeneous distributions and poorly understood emission inventories over some parts of the world. SEN-C1-fEMIS is designed to assess how such uncertainties in anthropogenic emissions of non-methane $\mathrm{O}_{3}$ precursors might affect the $\mathrm{O}_{3}$ evolution. We take the results of SEN-C1-fEMIS from 1987 to 2010 and display the anomaly and trend of $\mathrm{O}_{3}$ in the same manner as $\mathrm{O}_{3}$ from the REF-C1 simulation (Fig. 7). The comparison shows that there is no apparent difference between $\mathrm{O}_{3}$ trends in the troposphere between these two simulations, but there are distinct differences from the tropopause region to $25 \mathrm{~km}$. However, the very high REF-C1 $\mathrm{O}_{3}$ anomalies at the beginning of the record might contribute in part to the very negative trends in the strato- 

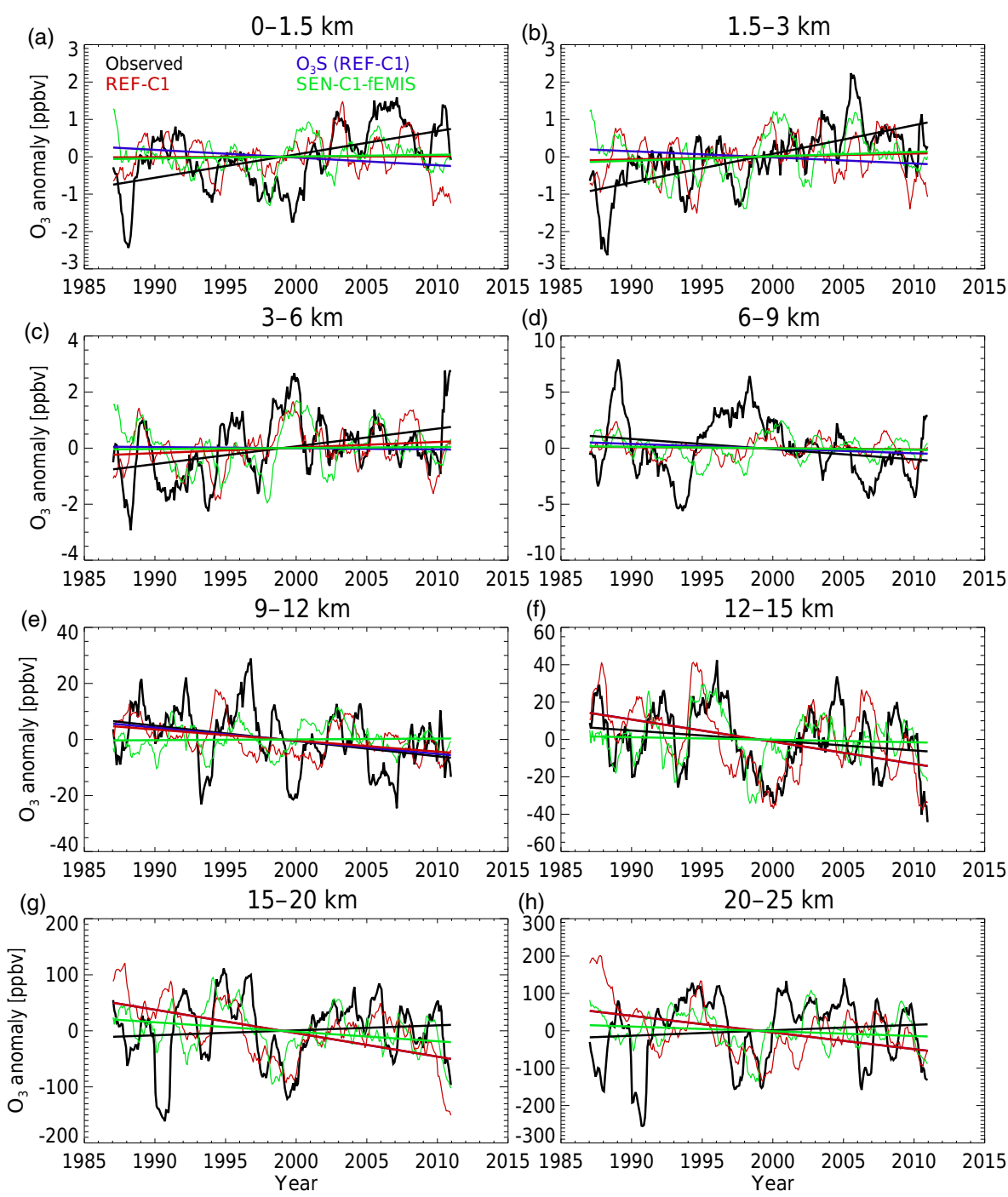

Figure 7. Observed (black) and modelled $\mathrm{O}_{3}$ anomalies and corresponding linear trends, from REF-C1 (red) and SEN-C1-fEMIS (green), respectively, at Lauder (1987-2010), and the linear trend in $\mathrm{O}_{3} \mathrm{~S}$ (blue line) from REF-C1. Anomalies shown are smoothed with a 13-monthly filter for the purpose of display.

Table 5. Attributions of modelled trends ( \pm 1 standard deviation) due to changes in non-methane $\mathrm{O}_{3}$ precursors $(\mathrm{NMOPs}), \mathrm{CH}_{4}, \mathrm{GHGs}$, and ODSs over the period 1987-2010 and 1987-2014, respectively, calculated as trends in absolute differences between $\mathrm{O}_{3}$ anomalies from the sensitivity simulations and $\mathrm{O}_{3}$ anomalies from the REF-C1 and REF-C2 simulation, respectively. Units are ppbv year ${ }^{-1}$.

\begin{tabular}{lrrrr}
\hline Altitude $(\mathrm{km})$ & $\begin{array}{r}\text { Due to NMOPs } \\
1987-2010\end{array}$ & $\begin{array}{r}\text { Due to } \mathrm{CH}_{4} \\
1987-2014\end{array}$ & $\begin{array}{r}\text { Due to GHGs } \\
1987-2014\end{array}$ & $\begin{array}{r}\text { Due to ODSs } \\
1987-2014\end{array}$ \\
\hline $0-1.5$ & $-0.00 \pm 0.01$ & $0.02 \pm 0.02$ & $-0.00 \pm 0.01$ & $-0.02 \pm 0.01$ \\
$1.5-3$ & $-0.00 \pm 0.02$ & $0.02 \pm 0.02$ & $-0.00 \pm 0.01$ & $-0.03 \pm 0.02$ \\
$3-6$ & $0.02 \pm 0.02$ & $0.02 \pm 0.02$ & $-0.01 \pm 0.02$ & $-0.05 \pm 0.02$ \\
$6-9$ & $0.00 \pm 0.03$ & $0.00 \pm 0.03$ & $0.00 \pm 0.02$ & $-0.08 \pm 0.03$ \\
$9-12$ & $-0.42 \pm 0.16$ & $-0.05 \pm 0.11$ & $0.20 \pm 0.11$ & $0.02 \pm 0.12$ \\
$12-15$ & $-1.05 \pm 0.40$ & $0.23 \pm 0.51$ & $0.69 \pm 0.33$ & $0.14 \pm 0.37$ \\
$15-20$ & $-2.49 \pm 0.91$ & $0.50 \pm 1.56$ & $1.27 \pm 0.79$ & $-0.11 \pm 0.92$ \\
$20-25$ & $-3.20 \pm 1.24$ & $1.80 \pm 1.99$ & $3.91 \pm 1.01$ & $0.52 \pm 1.09$ \\
\hline
\end{tabular}



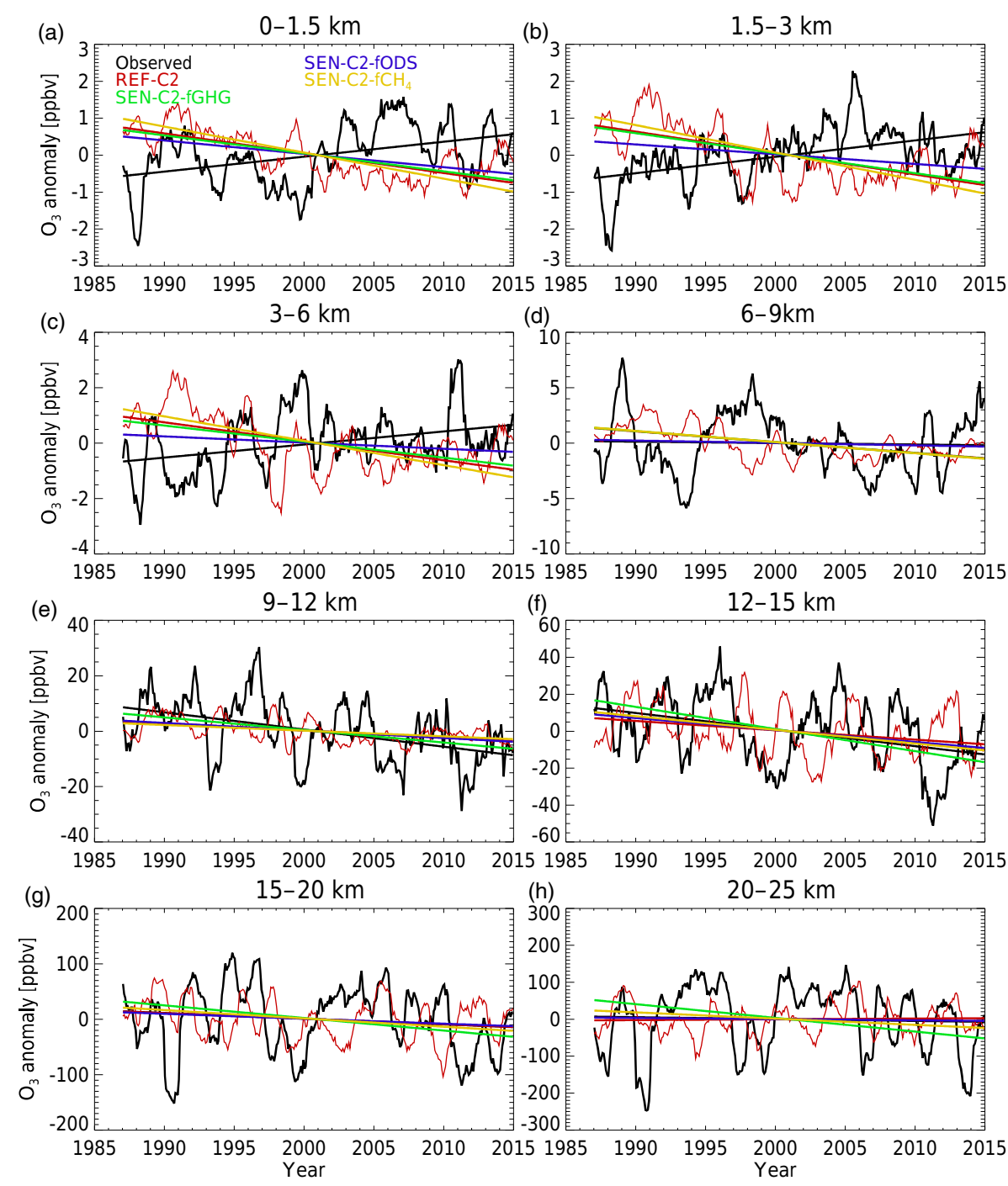

Figure 8. Observed (black) and modelled (REF-C2; red) $\mathrm{O}_{3}$ anomalies and linear trends at Lauder over 1987-2014. Modelled linear trends from SEN-C2-fGHG (green line), SEN-C2-fCH 4 (gold line), and SEN-C2-fODS (blue line) are also depicted. Anomalies shown are smoothed with a 13-monthly filter for the purpose of display.

sphere. The response of $\mathrm{O}_{3}$ trend to changing non-methane $\mathrm{O}_{3}$ precursors is quantified and shown in Table 5. Overall, the non-methane $\mathrm{O}_{3}$ precursor emission changes between the late 1980s and 2010 have no significant effects on tropospheric $\mathrm{O}_{3}$ trends, whereas in the stratosphere, the simulation with constant emissions shows flat or slightly negative trends in $\mathrm{O}_{3}$, which indicates changes in emissions (both $\mathrm{NO}_{x}$ and $\mathrm{CO}$ surface emissions show global increases during this period; Fig. 1, and Fig. 1 in Morgenstern et al., 2017) contribute to the negative trends in stratospheric $\mathrm{O}_{3}$.

The stratospheric tracer $\mathrm{O}_{3} \mathrm{~S}$ depicted in Fig. 7 shows a weak but significant negative trend near the surface (Table 4). This decrease is likely the result of a decrease in stratospheric $\mathrm{O}_{3}$ over this period. $\mathrm{O}_{3} \mathrm{~S}$ is a measure of $\mathrm{O}_{3}$ originating from the stratosphere, and the negative trend in
$\mathrm{O}_{3} \mathrm{~S}$ also implies that the photochemical production of $\mathrm{O}_{3}$ in the lower troposphere is increasing, most likely as a result of increasing $\mathrm{O}_{3}$ precursors including methane. We mentioned before that there seems to be an increase in deep stratospheric intrusion at Lauder over the period of 1987-2014, as indicated by a negative trend in relative humidity. Clearly, STE plays an important role also in controlling lower tropospheric $\mathrm{O}_{3}$, but a more rigorous attribution of the trend in near-surface $\mathrm{O}_{3}$ would require a more dedicated set of model experiments, which might be a worthwhile topic for future research. 


\subsection{REF-C2 simulation and the impact from ODSs, GHGs, and $\mathrm{CH}_{4}$}

In Fig. 8, we compare $\mathrm{O}_{3}$ anomalies and their trends from the REF-C2 simulations to those from observations for the period of 1987-2014. The variations of observed $\mathrm{O}_{3}$ anomalies are less accurately matched by the REF-C 2 simulations, which are free-running simulations not constrained by observed sea surface conditions, as opposed to the REF-C1 simulations, which are driven by observed sea surface conditions. Significant negative trends in $\mathrm{O}_{3}$ anomalies are calculated for the tropospheric layers, which are reflected neither in the observed trends nor in the REF-C1 simulations, which yield a flat trend in the troposphere (Fig. 7). The significant negative tropospheric $\mathrm{O}_{3}$ trends in REF-C2 are most likely the consequence of a sharp drop in surface $\mathrm{NO}_{x}$ emissions after the year 2000 in the REF-C2 simulations, due to adopting a different emission dataset in 2000 (RCP6.0) that differs from the MACCity emission inventory used in REF$\mathrm{C} 1$ (see Fig. 1 and a related discussion in Morgenstern et al., 2017). This discrepancy in $\mathrm{NO}_{x}$ emissions between REF-C1 and REF-C2 simulations results in significant differences in modelled $\mathrm{O}_{3}$ trends at Lauder, a background $\mathrm{SH}$ mid-latitude site, indicating the important role of surface emissions of $\mathrm{O}_{3}$ precursors impacting $\mathrm{SH} \mathrm{O}_{3}$ trends, most likely through inter-hemispheric transport. However, around the tropopause and in the stratosphere, the REF-C2 simulation reproduces the observed $\mathrm{O}_{3}$ trends, in contrast to the REF-C1 simulations, although the variations in observed $\mathrm{O}_{3}$ are less well reproduced in REF-C2 than in REF-C1.

The purpose of using REF-C2 and SEN-C2 simulations is to assess the role of key forcing agents (ODSs, GHGs, and $\mathrm{CH}_{4}$ ) in affecting the long term $\mathrm{O}_{3}$ trend. In Fig. 8, we also display the $\mathrm{O}_{3}$ trends from the sensitivity runs. For the fixedODS run (i.e. SEN-C2-fODS), the negative trends in $\mathrm{O}_{3}$ are smaller in magnitudes than those from REF-C2 in the troposphere, which indicates that changes (i.e. increases) in ODSs between 1987 and 2015 would decrease the tropospheric $\mathrm{O}_{3}$. However, there is no significant difference in trends between REF-C2 and SEN-C2-fODS simulations in the stratosphere. Halogen loading in the atmosphere (Fig. 1) peaked in the 1990s and then dropped gradually approximately to the late 1980s level in 2014. This could explain the relatively small overall impact from ODSs over the period of 1987-2014 on $\mathrm{O}_{3}$ at Lauder. The negative impact of ODSs changes during this period on tropospheric $\mathrm{O}_{3}$ is also reflected in the $\mathrm{O}_{3} \mathrm{~S}$ tracer, which shows a small but significant negative trend over this period (Fig. 7). Changes in GHGs over the period of 1987-2014 produce a negligible impact on simulated tropospheric $\mathrm{O}_{3}$ changes at Lauder, but they have a significant impact on trends in stratospheric $\mathrm{O}_{3}$ (above $12 \mathrm{~km}$ ) (Fig. 8). The significant negative trends of $\mathrm{O}_{3}$ in the fixed-GHGs simulations in the stratosphere imply increases in GHGs over 1987-2015 would contribute positively to the stratospheric $\mathrm{O}_{3}$ trends. The effect is due to changes in $\mathrm{CO}_{2}, \mathrm{CH}_{4}$, and
$\mathrm{N}_{2} \mathrm{O}$ collectively. We also performed a sensitivity simulation (SEN-C2-fCH $\mathrm{CH}_{4}$ ) with only $\mathrm{CH}_{4}$ fixed at the 1960 level, to separate the effect of $\mathrm{CH}_{4}$ from other GHGs, e.g. $\mathrm{CO}_{2}$ and $\mathrm{N}_{2} \mathrm{O} . \mathrm{CH}_{4}$ is an $\mathrm{O}_{3}$ precursor and also a GHG (see above). This analysis shows that in SEN-C2- $\mathrm{fCH}_{4}$, significant negative trends in $\mathrm{O}_{3}$ are calculated throughout the troposphere, as shown in Fig. 8, indicating that the increase in $\mathrm{CH}_{4}$ over the period of 1987-2015 contributes positively to tropospheric $\mathrm{O}_{3}$ trends. Very similar $\mathrm{O}_{3}$ trends in the REF-C2 and SEN-C2-fGHG simulations imply that increases in $\mathrm{CO}_{2}$ and $\mathrm{N}_{2} \mathrm{O}$ would make negligible or slightly negative contributions to the $\mathrm{O}_{3}$ trends over this period, outweighing the positive contribution of increasing $\mathrm{CH}_{4}$. In the stratosphere, $\mathrm{CH}_{4}$ through changes in chemistry plays a much less significant role in $\mathrm{O}_{3}$ trends.

Note that the period analysed (1987-2014) is relatively short, and the overall changes in ODSs and GHGs (including $\mathrm{CH}_{4}$ ) are relatively small. Consequently, changes in $\mathrm{O}_{3}$ trends attributable to these climate/chemical forcings are usually associated with large uncertainties and therefore not significant at $95 \%$ confidence level (Table 5). Overall, changes in $\mathrm{CH}_{4}$ contribute positively to tropospheric $\mathrm{O}_{3}$ trends through enhanced photochemical production of $\mathrm{O}_{3}$. Increases in GHGs alone seem to result in decreasing tropospheric $\mathrm{O}_{3}$ (presumably via enhanced chemical destruction in a future warmer and wetter climate), although this is counterbalanced by increasing tropospheric $\mathrm{O}_{3}$ through $\mathrm{CH}_{4}$ oxidation. Increasing ODSs lead to significant negative $\mathrm{O}_{3}$ trend in the troposphere, through downward transport of stratospheric $\mathrm{O}_{3}$. In the stratosphere, the effect from ODSs is small due to the overall small changes in ODS over this period, whilst increases in GHGs seem to be the major forcing, contributing positively to stratospheric $\mathrm{O}_{3}$ trends through, possibly, decelerated $\mathrm{O}_{3}$ destruction due to cooling. This positive contribution may have outweighed any reduction of stratospheric $\mathrm{O}_{3}$ resulting from negative $\mathrm{O}_{3}$ trends that is triggered by dynamical changes in the tropopause region, as both observations and REF-C2 simulations show relatively small and insignificant trends in stratospheric $\mathrm{O}_{3}$ at Lauder. In the tropopause region, $\mathrm{O}_{3}$ trends are not sensitive to changes in these forcings, and are largely controlled by dynamical changes, e.g. the movement of the tropopause. Both REF$\mathrm{C} 1$ and REF-C2 produce a positive, albeit smaller than observed, trend in tropopause height, which agrees with the scientific finding that anthropogenic forcings, in particular $\mathrm{O}_{3}$ and well-mixed GHG changes, contribute predominantly to observed tropopause height increase in recent decades (e.g. Santer et al., 2003).

In the following section, we expand the analysis to include the whole simulation period of 1960-2010 and assess longterm simulated changes in $\mathrm{O}_{3}$ at $\mathrm{SH}$ mid-latitudes (represented by Lauder) due to changes in anthropogenic forcings of ODS, GHGs, and $\mathrm{O}_{3}$ precursor emissions. 


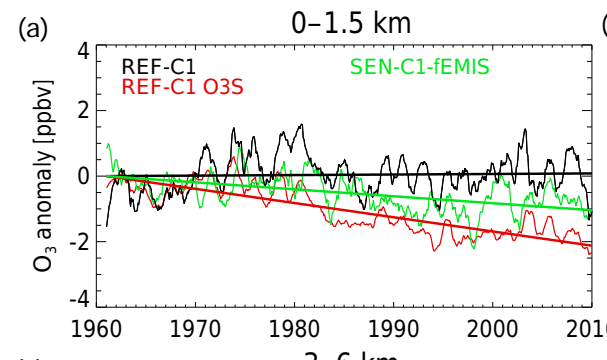

(b) $\quad 1.5-3 \mathrm{~km}$
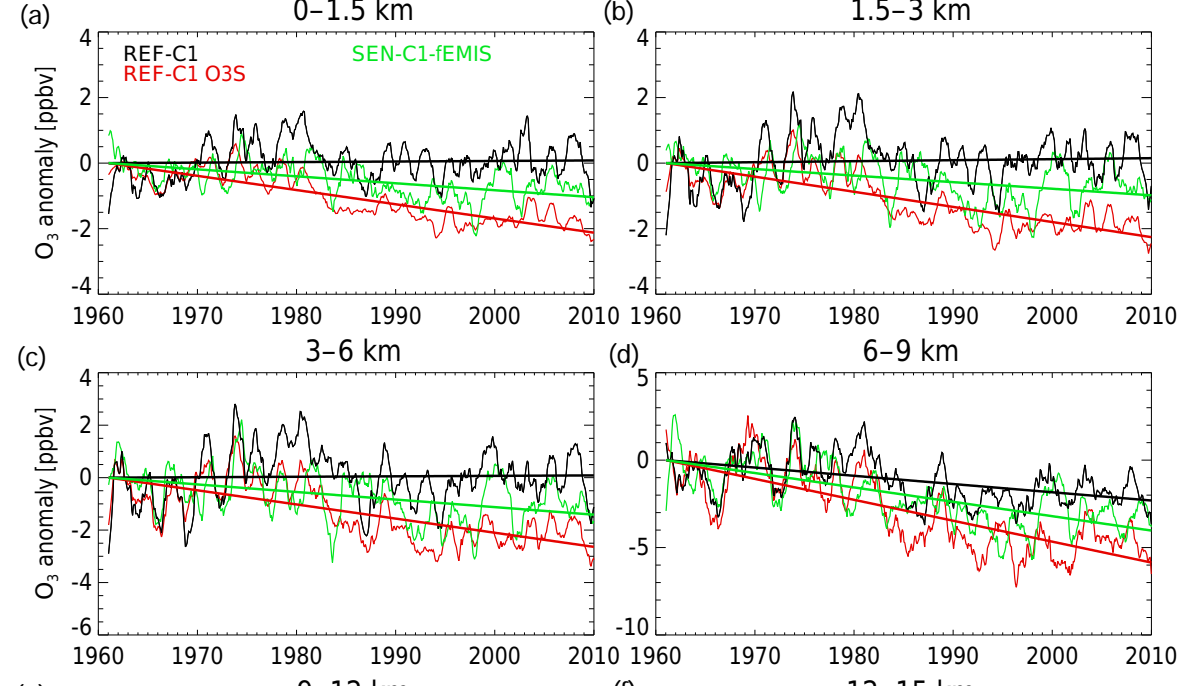

(d)
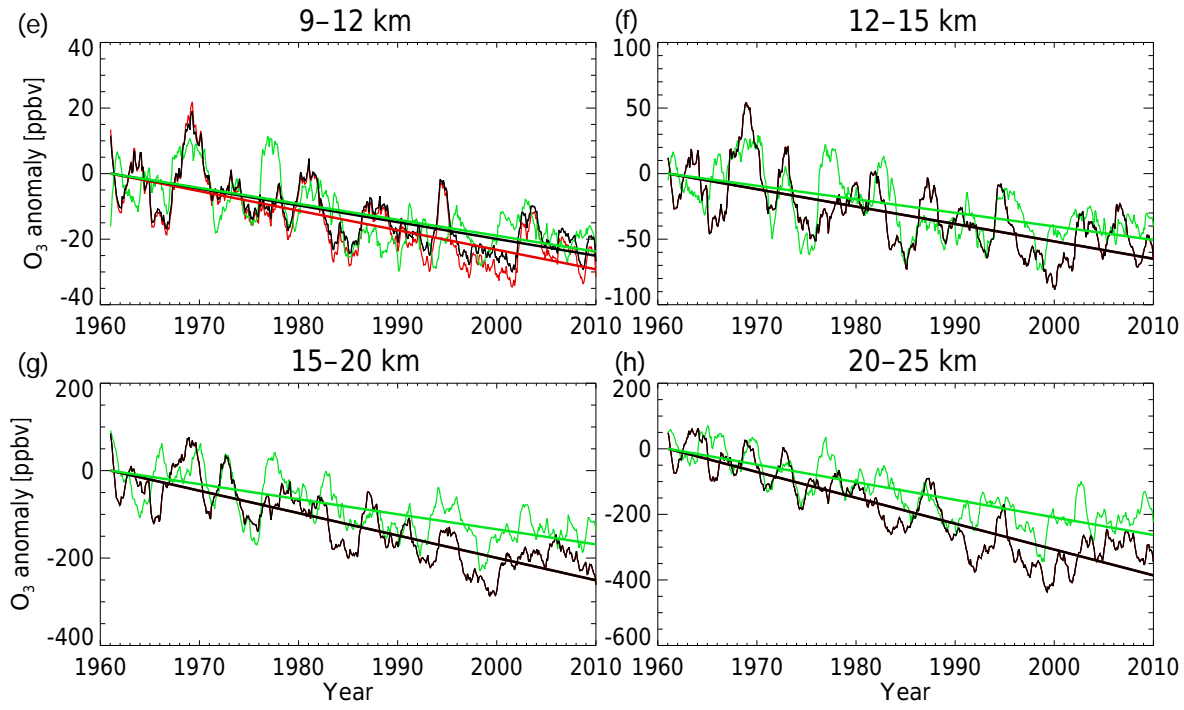

Figure 9. Modelled $\mathrm{O}_{3}$ anomalies and linear trends at Lauder over 1960-2010 from REF-C1 (black) and SEN-C1-fEMIS (green), respectively. The anomaly and linear trend of stratospheric $\mathrm{O}_{3}$ tracer $\left(\mathrm{O}_{3} \mathrm{~S}\right)$ are also depicted (red). Anomalies shown are smoothed with a 13-monthly filter for the purpose of display.

\subsection{Modelled attribution to long-term $\mathrm{O}_{3}$ changes at Lauder}

Figures 9 and 10 display the $\mathrm{O}_{3}$ evolution and trends over the 1960-2010 period from REF-C1 and REF-C2, respectively, and the associated sensitivity simulations. The $\mathrm{O}_{3}$ anomalies are all normalised to zero at the starting time point. The analysis shows that in both simulations, $\mathrm{O}_{3}$ shows insignificant or moderately negative trends in the troposphere, and more significant negative trends in the stratosphere (Table 6). It should be noted that larger negative trends in stratospheric $\mathrm{O}_{3}$ are simulated in REF-C1 than those in REF-fC2; there are sustained stratospheric $\mathrm{O}_{3}$ losses prior to the 1980s in REF$\mathrm{C} 1$, which are not present in REF-C2 simulations. Relative to the period of Lauder $\mathrm{O}_{3}$ sonde observations, both simulations show stratospheric $\mathrm{O}_{3}$ losses from the 1980s to around
2000, and then $\mathrm{O}_{3}$ recovery after the year 2000 (Figs. 9 and 10), although such changes are not obvious in observed lower stratospheric $\mathrm{O}_{3}$ at Lauder because of large variability (Figs. 7 and 8).

Examining the sensitivity simulation SEN-C1-fEMIS, fixing emissions at the 1960 level results in negative trends throughout the domain, but with larger negative trends in the troposphere and smaller negative trends in the stratosphere, compared to REF-C1. This means that increases in $\mathrm{O}_{3}$ precursor emissions since the 1960s lead to a positive contribution to tropospheric $\mathrm{O}_{3}$ (shown in Fig. 9), predominantly through increased chemical $\mathrm{O}_{3}$ production. However, increases in $\mathrm{O}_{3}$ precursor emissions cause a reduction in stratospheric $\mathrm{O}_{3}$; we can only suspect that this is due to chemical and/or dynamical changes in the lower stratosphere as a result of $\mathrm{O}_{3}$ feedback, and this warrants further investi- 

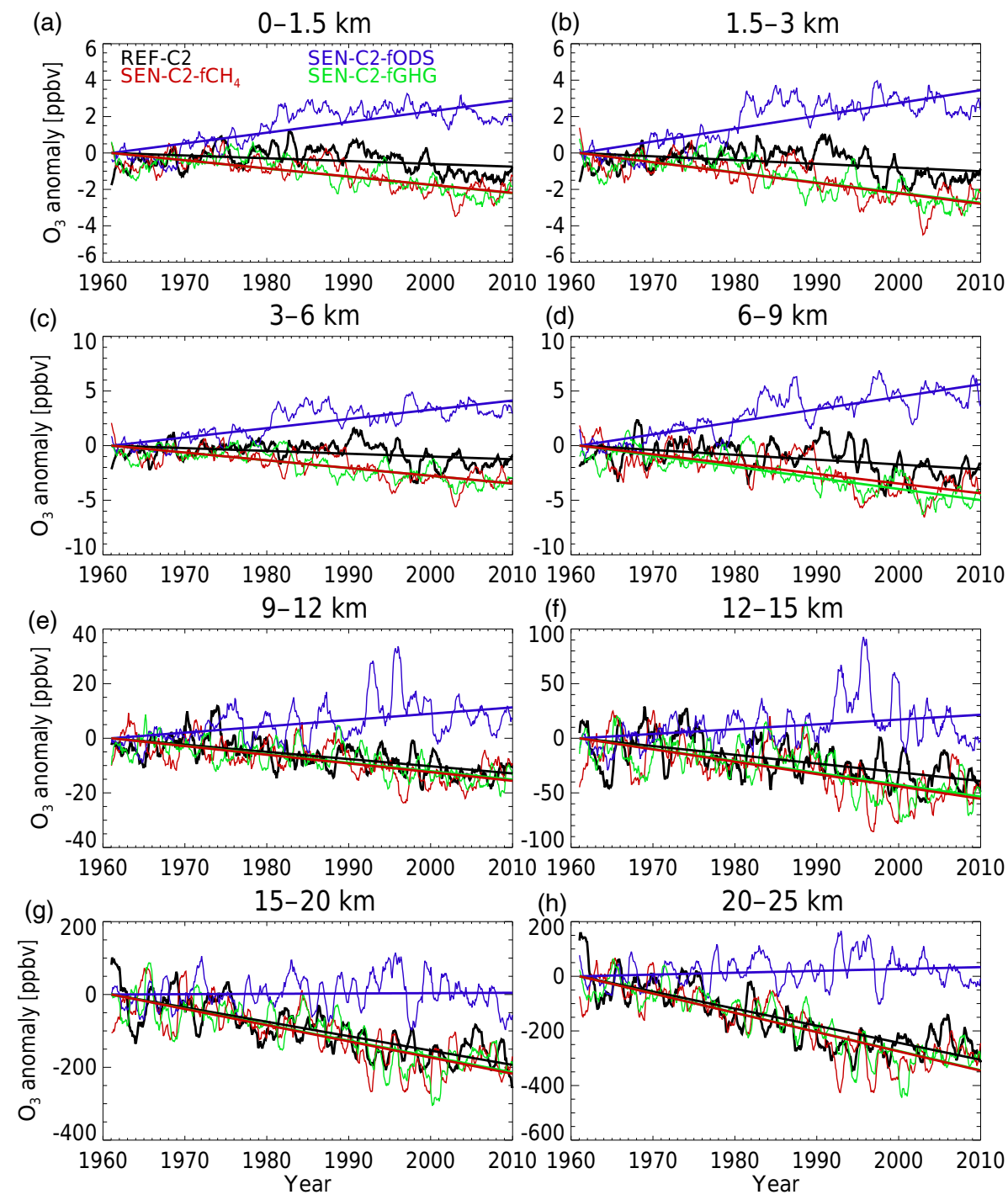

Figure 10. Modelled $\mathrm{O}_{3}$ anomalies and linear trends at Lauder over 1960-2010, from REF-C2 (black), SEN-C2-fGHG (green), SEN-C2$\mathrm{fCH}_{4}$ (red), and SEN-C2-fODS (blue). Anomalies shown are smoothed with a 13-monthly filter for the purpose of display.

Table 6. Simulated trends in $\mathrm{O}_{3}$ and $\mathrm{O}_{3} \mathrm{~S}$ anomalies ( \pm 1 standard deviation) at Lauder, and attributions of modelled trends due to changes in non-methane $\mathrm{O}_{3}$ precursors, $\mathrm{CH}_{4}$, GHGs, and ODSs over the period of 1960-2010. Units are ppbv year ${ }^{-1}$.

\begin{tabular}{lrrrrrrr}
\hline Altitude $(\mathrm{km})$ & REF-C1 & REF-C2 & Due to NMOPs & Due to $\mathrm{CH}_{4}$ & Due to GHGs & Due to ODSs & $\mathrm{O}_{3} \mathrm{~S}$ (REF-C1) \\
\hline $0-1.5$ & $0.00 \pm 0.00$ & $-0.02 \pm 0.00$ & $0.02 \pm 0.01$ & $0.03 \pm 0.01$ & $0.03 \pm 0.01$ & $-0.07 \pm 0.01$ & $-0.04 \pm 0.00$ \\
$1.5-3$ & $0.00 \pm 0.00$ & $-0.02 \pm 0.00$ & $0.02 \pm 0.01$ & $0.04 \pm 0.01$ & $0.04 \pm 0.01$ & $-0.09 \pm 0.01$ & $-0.05 \pm 0.00$ \\
$3-6$ & $0.00 \pm 0.01$ & $-0.03 \pm 0.01$ & $0.03 \pm 0.01$ & $0.05 \pm 0.01$ & $0.05 \pm 0.01$ & $-0.11 \pm 0.01$ & $-0.05 \pm 0.00$ \\
$6-9$ & $-0.05 \pm 0.01$ & $-0.04 \pm 0.01$ & $0.04 \pm 0.01$ & $0.05 \pm 0.01$ & $0.06 \pm 0.01$ & $-0.16 \pm 0.01$ & $-0.12 \pm 0.01$ \\
$9-12$ & $-0.51 \pm 0.05$ & $-0.26 \pm 0.04$ & $-0.26 \pm 0.06$ & $0.06 \pm 0.05$ & $0.05 \pm 0.05$ & $-0.49 \pm 0.05$ & $-0.60 \pm 0.05$ \\
$12-15$ & $-1.33 \pm 0.13$ & $-0.80 \pm 0.11$ & $-0.29 \pm 0.15$ & $0.33 \pm 0.16$ & $0.29 \pm 0.16$ & $-1.24 \pm 0.16$ & $-1.33 \pm 0.13$ \\
$15-20$ & $-5.12 \pm 0.26$ & $-3.95 \pm 0.26$ & $-1.68 \pm 0.33$ & $0.49 \pm 0.39$ & $0.42 \pm 0.38$ & $-4.05 \pm 0.38$ & $-5.12 \pm 0.26$ \\
$20-25$ & $-7.88 \pm 0.31$ & $-6.25 \pm 0.34$ & $-2.51 \pm 0.41$ & $0.81 \pm 0.48$ & $0.77 \pm 0.45$ & $-6.93 \pm 0.47$ & $-7.88 \pm 0.31$ \\
\hline
\end{tabular}


gation. In the tropopause region (9-12 km), the impact on $\mathrm{O}_{3}$ trends from fixed emissions is minimal, which may suggest that changes in $\mathrm{O}_{3}$ at the tropopause are mainly controlled by the movement of the tropopause rather than changes in $\mathrm{O}_{3}$ precursors in the troposphere, and indeed, our calculation shows that there is no significant difference in modelled tropopause heights between SEN-C1-fEMIS and REF$\mathrm{C} 1$ simulations. In addition, the stratospheric tracer $\mathrm{O}_{3} \mathrm{~S}$ from REF-C1 is also shown, which shows negative trends, as a result of the declining stratospheric $\mathrm{O}_{3}$ during this period.

In the fixed-ODS simulations, large differences in $\mathrm{O}_{3}$ trends from the correspondent $\mathrm{O}_{3}$ trends in REF-C2 are shown (Fig. 10), indicating significant negative contributions to $\mathrm{O}_{3}$ trends due to changes (i.e. increases) in ODSs between 1960 and 2010. By comparison, changes in GHGs seem to have less impact on $\mathrm{O}_{3}$ trends than ODS changes. Increases in GHGs generally contribute positively to $\mathrm{O}_{3}$ trends over this period, and the largest influence occurs in the troposphere, whereas the impact on stratospheric $\mathrm{O}_{3}$ trends is negligible. Interestingly, the impact of changing GHGs on $\mathrm{O}_{3}$ trends is shown mainly through $\mathrm{CH}_{4}$ changes, suggesting that chemical changes $\left(\mathrm{O}_{3}\right.$ production through increased $\left.\mathrm{CH}_{4}\right)$ are likely to dominate the contribution of changing GHGs to $\mathrm{O}_{3}$ trends, especially given that the contribution mainly occurs in the troposphere (Fig. 10). We can not identify in this study the role of individual GHGs in moderating $\mathrm{O}_{3}$ trends, and it is possible that radiative feedbacks are different from different GHGs, and chemical feedbacks also differ, e.g. $\mathrm{CH}_{4}$ contributes to $\mathrm{O}_{3}$ chemical production and $\mathrm{N}_{2} \mathrm{O}$ plays a role in stratospheric $\mathrm{O}_{3}$ destruction. The attribution of modelled $\mathrm{O}_{3}$ trends to each of the aforementioned forcings is listed in Table 6.

\section{Conclusions}

We have analysed a 28-year ozonesonde record from Lauder, covering 1987 to 2014, and a surface $\mathrm{O}_{3}$ record from Baring Head covering 1992 to 2015. Both background measurement sites are located in the SH mid-latitudes and are representative of background atmospheric conditions. We have also analysed some meteorological parameters that are comeasured with $\mathrm{O}_{3}$ at Lauder, and have explored the relationships between $\mathrm{O}_{3}$ changes and changes in these parameters, i.e. surface relative humidity, surface and stratospheric temperatures, and tropopause height. Through a regression analysis of ozonesonde data, which involves grouping the profiles into eight layers extending to the stratosphere $(25 \mathrm{~km})$, we have identified the dominant meteorological parameters that control the interannual variations of $\mathrm{O}_{3}$ at Lauder. We find that relative humidity dominates the variability of lower tropospheric $\mathrm{O}_{3}$, possibly through deep stratospheric intrusions, and that $\mathrm{O}_{3}$ variability around the tropopause region is dominated by the movement of the tropopause. In addition, ENSO contributes to $\mathrm{O}_{3}$ variations in the free troposphere, and the $\mathrm{QBO}$ and solar cycle impact $\mathrm{O}_{3}$ variations in the stratosphere.

The trends in observed $\mathrm{O}_{3}$ at Lauder have been calculated for the eight layers. Significant positive trends in the troposphere below $6 \mathrm{~km}$, and significant negative trends in the tropopause region are obtained, for both 1987-2010 and 1987-2014. No significant trends are found in the upper troposphere $(6-9 \mathrm{~km})$ and in the stratosphere (above $15 \mathrm{~km}$ ). A significant negative $\mathrm{O}_{3}$ trend in the $9-12 \mathrm{~km}$ region is very likely the result of an increasing tropopause height at Lauder. Such a dynamically induced change in $\mathrm{O}_{3}$ also propagates to below and above the tropopause. Changes in temperatures in both the troposphere and the stratosphere impact $\mathrm{O}_{3}$ by modifying the chemical production and destruction rates. Specifically, increased surface temperature would enhance photochemical production of $\mathrm{O}_{3}$ mainly in the lower troposphere, and decreased stratospheric temperature would slow down the nitrogen- and halogen-catalysed $\mathrm{O}_{3}$ destruction cycles. Such effects from temperature changes could be balanced by the effect from tropopause height changes; the net impact is small $\mathrm{O}_{3}$ trends in the upper troposphere and the lower stratosphere.

We have used NIWA-UKCA chemistry-climate model simulations to attribute $\mathrm{O}_{3}$ trends observed at Lauder to anthropogenic influences, particularly changing GHGs, ODSs, and $\mathrm{O}_{3}$ precursors over 1987 to 2014. Results from these CCMI simulations indicate that $\mathrm{O}_{3}$ precursor emissions have no net impact on tropospheric $\mathrm{O}_{3}$ but lead to significant negative trends in stratospheric $\mathrm{O}_{3}$; this will be further investigated. Changes in $\mathrm{CH}_{4}$ generally have a positive impact on $\mathrm{O}_{3}$, but the effect is not significant at the $95 \%$ confidence level. Changes in GHGs (including $\mathrm{CH}_{4}$ ) mainly affect the stratosphere, where increased GHGs lead to significant positive trends in $\mathrm{O}_{3}$. Increases in ODSs during this period mainly result in negative $\mathrm{O}_{3}$ trend in the troposphere, through STE and/or consequences for tropospheric ozone photochemistry. But with $\mathrm{Br}_{y}$ and $\mathrm{Cl}_{y}$ peaking in the late 1990 s, stratospheric $\mathrm{O}_{3}$ at Lauder is not significantly affected by overall changes in ODSs from 1987 to 2014 . We also examined $\mathrm{O}_{3}$ transported from the stratosphere using a diagnostic stratospheric $\mathrm{O}_{3}$ tracer, which shows a significant negative trend near the surface, suggesting that changes in STE of ozone are indeed involved in tropospheric ozone trends.

The observed significant positive trend in tropospheric $\mathrm{O}_{3}$ below $6 \mathrm{~km}$ is not reproduced by the base simulations (REF$\mathrm{C} 1$ and REF-C2), which is very likely because of an underestimation of positive trends in surface emissions of $\mathrm{O}_{3}$ precursors. The large significant negative trend in stratospheric $\mathrm{O}_{3}$ in the REF-C1 simulation is caused by the very large positive anomaly at the beginning of $\mathrm{O}_{3}$ record. Both base simulations reproduce the significant negative $\mathrm{O}_{3}$ trend in the tropopause region well, associated with dynamical changes.

The Lauder $\mathrm{O}_{3}$ record presented in this study is relatively short for detecting significant responses of $\mathrm{O}_{3}$ to changes in GHGs, ODSs, and $\mathrm{O}_{3}$ precursors. The analysis is extended 
to cover the whole period of the simulation, i.e. 1960-2010, during which period significant changes in GHGs, ODSs, and $\mathrm{O}_{3}$ precursors occur, allowing for a more robust assessment of their impacts on the $\mathrm{O}_{3}$ evolution. The results show that all forcings contribute significantly to simulated $\mathrm{O}_{3}$ trends over the last five decades at Lauder. Increases in $\mathrm{O}_{3}$ precursors contribute positively to tropospheric $\mathrm{O}_{3}$ through enhanced photochemical production of $\mathrm{O}_{3}$, but negatively to stratospheric $\mathrm{O}_{3}$. The increase in $\mathrm{CH}_{4}$ leads to positive $\mathrm{O}_{3}$ trends in both the troposphere and the stratosphere, and is comparable to the $\mathrm{O}_{3}$ response to the net effect of combined GHG changes, indicating there may be a cancellation of effects from increases in $\mathrm{CO}_{2}$ and in $\mathrm{N}_{2} \mathrm{O}$. The overall increase in ODSs between 1960 and 2010 results in significant negative trend in tropospheric and stratospheric $\mathrm{O}_{3}$, which coincides with the negative trend in the stratospheric $\mathrm{O}_{3}$ tracer.

This study demonstrates that long-term ozone profile observations provide valuable insight into atmospheric composition changes associated with anthropogenic forcing over the recent decades at a background SH mid-latitude location. More locations can be explored in future studies and multimodel simulation ensembles can be used to derive global $\mathrm{O}_{3}$ changes and to project the future evolution.

Data availability. All data used in this paper can be obtained from the contact author. The Lauder ozonesonde data are available at ftp: //ftp.cpc.ncep.noaa.gov/ndacc/station/lauder/ames/o3sonde/ Baring Head surface $\mathrm{O}_{3}$ data are available at http://ds.data.jma.go.jp/gmd/ wdcgg. NIWA-UKCA simulations can be downloaded from the CCMI archive; see instructions at http://blogs.reading.ac.uk/ccmi/ badc-data-access/

Competing interests. The authors declare that they have no conflict of interest.

Special issue statement. This article is part of the special issue "Twenty-five years of operations of the Network for the Detection of Atmospheric Composition Change (NDACC) (AMT/ACP/ESSD inter-journal SI)". It is not associated with a conference.

Acknowledgements. We acknowledge the NIWA Lauder Ozone team for ozone sonde measurements since 1986, and technicians involved at various stages of data collection. We acknowledge the UK Met Office for use of the MetUM. Furthermore, we acknowledge the contribution of NeSI high-performance computing facilities to the results of this research. NZ's national facilities are provided by the NZ eScience Infrastructure and funded jointly by NeSI's collaborator institutions and through the Ministry of Business, Innovation \& Employment's Research Infrastructure programme (https://www.nesi.org.nz). This research was supported by the NZ Government's Strategic Science Investment Fund (SSIF) through the NIWA programmes CACV and CAAC, and by the Marsden Fund Council from New Zealand Government funding, managed by the Royal Society of New Zealand, under project 12NIW006.

Edited by: Hal Maring

Reviewed by: two anonymous referees

\section{References}

Beekmann, M., Ancellet, G., and Mégie, G.: Climatology of tropospheric ozone in Southern Europe and its relation to potential vorticity, J. Geophys. Res., 99, 12841-12853, 1994.

Bethan, S., Vaughan, G., and Reid, S. J.: A comparison of ozone and thermal tropopause heights and the impact of tropopause definition on quantifying the ozone content of the troposphere, Q. J Roy. Meteor. Soc., 122, 929-944, 1996.

Bodeker, G. E., Boyd, I. S., and Matthews, W. A.: Trends and variability in vertical ozone and temperature profiles measured by ozonesondes at Lauder, New Zealand: 1986-1996, J. Geophys. Res., 103, 28661-28682, 1998.

Boyd, I. S., Bodeker, G. E., Connor, B. J., Swart, D. P. J., and Brinksma, E. J.: An assessment of ECC ozonesondes operated using $1 \%$ and $0.5 \% \mathrm{KI}$ cathode solutions at Lauder, New Zealand, Geophys. Res. Lett., 25, 2409-2412, 1998.

Cristofanelli, P., Bonasoni, P., Tositti, L., Bonafè, U., Calzolari, F., Evangelisti, F., Sandrini, S., and Stohl, A.: A 6-year analysis of stratospheric intrusions and their influence on ozone at Mt. Cimone (2165 $\mathrm{m}$ above sea level), J. Geophy. Res.-Atmos., 111, D03306, https://doi.org/10.1029/2005JD006553, 2006.

Eyring, V., Cionni, I., Bodeker, G. E., Charlton-Perez, A. J., Kinnison, D. E., Scinocca, J. F., Waugh, D. W., Akiyoshi, H., Bekki, S., Chipperfield, M. P., Dameris, M., Dhomse, S., Frith, S. M., Garny, H., Gettelman, A., Kubin, A., Langematz, U., Mancini, E., Marchand, M., Nakamura, T., Oman, L. D., Pawson, S., Pitari, G., Plummer, D. A., Rozanov, E., Shepherd, T. G., Shibata, K., Tian, W., Braesicke, P., Hardiman, S. C., Lamarque, J. F., Morgenstern, O., Pyle, J. A., Smale, D., and Yamashita, Y.: Multimodel assessment of stratospheric ozone return dates and ozone recovery in CCMVal-2 models, Atmos. Chem. Phys., 10, 94519472, https://doi.org/10.5194/acp-10-9451-2010, 2010.

Eyring, V., Lamarque, J.-F., Hess, P., Arfeuille, F., Bowman, K., Chipperfield, M. P., Duncan, B., Fiore, A., Gettelman, A., Giorgetta, M. A., Granier, C., Hegglin, M., Kinnison, D., Kunze, M., Langematz, U., Luo, B., Martin, R., Matthes, K., Newman, P. A., Peter, T., Robock, A., Ryerson, T., Saiz-Lopez, A., Salawitch, R., Schultz, M., Shepherd, T. G., Shindell, D., Staehelin, J., Tegtmeier, S., Thomason, L., Tilmes, S., Vernier, J.-P., Waugh, D., and Young, P. J.: Overview of IGAC/SPARC Chemistry-Climate Model Initiative (CCMI) community simulations in support of upcoming ozone and climate assessments, SPARC Newsletter, 40, 48-66, 2013.

Granier, C., Bessagnet, B., Bond, T., DÁngiola, A., van der Gon, H. D., Frost, G. J., Heil, A., Kaiser, J. W., and Kinne, S.: Evolution of anthropogenic and biomass burning emissions of air pollutants at global and regional scales during the 1980-2010 period, Climatic Change, 109, 163-190, https://doi.org/10.1007/s10584-011-0154-1, 2011.

Guenther, A. B., Jiang, X., Heald, C. L., Sakulyanontvittaya, T., Duhl, T., Emmons, L. K., and Wang, X.: The Model of Emissions of Gases and Aerosols from Nature version 2.1 
(MEGAN2.1): an extended and updated framework for modeling biogenic emissions, Geosci. Model Dev., 5, 1471-1492, https://doi.org/10.5194/gmd-5-1471-2012, 2012.Hardiman, S. C., Butchart, N., O’Connor, F. M., and Rumbold, S. T.: The Met Office HadGEM3-ES chemistry-climate model: evaluation of stratospheric dynamics and its impact on ozone, Geosci. Model Dev., 10, 1209-1232, https://doi.org/10.5194/gmd-101209-2017, 2017.

Hardiman, S. C., Butchart, N., O'Connor, F. M., and Rumbold, S. T.: The Met Office HadGEM3-ES chemistryclimate model: evaluation of stratospheric dynamics and its impact on ozone, Geosci. Model Dev., 10, 1209-1232, https://doi.org/10.5194/gmd-10-1209-2017, 2017.

Hewitt, H. T., Copsey, D., Culverwell, I. D., Harris, C. M., Hill, R. S. R., Keen, A. B., McLaren, A. J., and Hunke, E. C.: Design and implementation of the infrastructure of HadGEM3: the next-generation Met Office climate modelling system, Geosci. Model Dev., 4, 223-253, https://doi.org/10.5194/gmd-4-2232011, 2011.

Lary, D. J. and Pyle, J. A.: Diffuse radiation, twilight, and photochemistry-I, J. Atmos. Chem., 13, 373-392, 1991.

Meinshausen, M., Smith, S. J., Calvin, K., Daniel, J. S., Kainuma, M. L., Lamarque, J.-F., Matsumoto, K., Montzka, S. A., Raper, S. C., Riahi, K., Thomson, A., Velders, G. J., and van Vuuren, D. P.: The RCP greenhouse gas concentrations and their extensions from 1765 to 2300 , Climatic Change, 109, 213-241, https://doi.org/10.1007/s10584-0110156-z, 2011.

Mitchell, J. F. B., Johns, T. C., Gregory, J. M., and Tett, S. F. B.: Climate response to increasing levels of greenhouse gases and sulphate aerosols, Nature, 376, 501-504, https://doi.org/10.1038/376501a0, 1995.

Morgenstern, O., Braesicke, P., O'Connor, F. M., Bushell, A. C., Johnson, C. E., Osprey, S. M., and Pyle, J. A.: Evaluation of the new UKCA climate-composition model Part 1: The stratosphere, Geosci. Model Dev., 2, 43-57, https://doi.org/10.5194/gmd-2-43-2009, 2009.

Morgenstern, O., Hegglin, M. I., Rozanov, E., O’Connor, F. M., Abraham, N. L., Akiyoshi, H., Archibald, A. T., Bekki, S., Butchart, N., Chipperfield, M. P., Deushi, M., Dhomse, S. S., Garcia, R. R., Hardiman, S. C., Horowitz, L. W., Jöckel, P., Josse, B., Kinnison, D., Lin, M., Mancini, E., Manyin, M. E., Marchand, M., Marécal, V., Michou, M., Oman, L. D., Pitari, G., Plummer, D. A., Revell, L. E., Saint-Martin, D., Schofield, R., Stenke, A., Stone, K., Sudo, K., Tanaka, T. Y., Tilmes, S., Yamashita, Y., Yoshida, K., and Zeng, G.: Review of the global models used within phase 1 of the Chemistry-Climate Model Initiative (CCMI), Geosci. Model Dev., 10, 639-671, https://doi.org/10.5194/gmd-10-639-2017, 2017.

Neu, J. L., Prather, M. J., and Penner, J. E.: Global atmospheric chemistry: Integrating over fractional cloud cover, J. Geophy. Res.-Atmos., 112, D11306, https://doi.org/10.1029/2006JD008007, 2007.

O’Connor, F. M., Johnson, C. E., Morgenstern, O., Abraham, N. L., Braesicke, P., Dalvi, M., Folberth, G. A., Sanderson, M. G., Telford, P. J., Voulgarakis, A., Young, P. J., Zeng, G., Collins, W. J., and Pyle, J. A.: Evaluation of the new UKCA climatecomposition model - Part 2: The Troposphere, Geosci. Model Dev., 7, 41-91, https://doi.org/10.5194/gmd-7-41-2014, 2014.
Oltmans, S., Lefohn, A., Harris, J., Galbally, I., Scheel, H., Bodeker, G., Brunke, E., Claude, H., Tarasick, D., Johnson, B., Simmonds, P., Shadwick, D., Anlauf, K., Hayden, K., Schmidlin, F., Fujimoto, T., Akagi, K., Meyer, C., Nichol, S., Davies, J., Redondas, A., and Cuevas, E.: Long-term changes in tropospheric ozone, Atmos. Environ., 40, 3156-3173, https://doi.org/10.1016/j.atmosenv.2006.01.029, 2006.

Oltmans, S. J., Lefohn, A. S., Shadwick, D., Harris, J. M., Scheel, H. E., Galbally, I., Tarasick, D. W., Johnson, B. J., Brunke, E.-G., Claude, H., Zeng, G., Nichol, S., Schmidlin, F., Davies, J., Cuevas, E., Redondas, A., Naoe, H., Nakano, T., and Kawasato, T.: Recent tropospheric ozone changes - a pattern dominated by slow or no growth, Atmos. Environ., 67, 331-351, https://doi.org/10.1016/j.atmosenv.2012.10.057, 2013.

Price, C. and Rind, D.: A simple lightning parameterization for calculating global lightning distributions, J. Geophys. Res., 97, 9919-9933, https://doi.org/10.1029/92JD00719, 1992.

Price, C. and Rind, D.: Modeling global lightning distributions in a general circulation model, Mon. Weather Rev., 122, 1930-1939, https://doi.org/10.1175/15200493(1994)122<1930:MGLDIA>2.0.CO;2, 1994.

Rayner, N. A., Parker, D. E., Horton, E. B., Folland, C. K., Alexander, L. V., Rowell, D. P., Kent, E. C., and Kaplan, A.: Global analyses of sea surface temperature, sea ice, and night marine air temperature since the late nineteenth century, J. Geophys. Res., 108, 4407, https://doi.org/10.1029/2002JD002670, 2003.

Santer, B. D., Taylor, K. E., Wigley, T. M. L., Johns, T. C., Jones, P. D., Karoly, D. J., Mitchell, J. F. B., Oort, A. H., Penner, J. E., Ramaswamy, V., Schwarzkopf, M. D., Stouffer, R. J., and Tett, S.: A search for human influences on the thermal structure of the atmosphere, Nature, 382, 39-46, https://doi.org/10.1038/382039a0, 1996.

Santer, B. D., Wehner, M. F., Wigley, T. M. L., Sausen, R., Meehl, G. A., Taylor, K. E., Ammann, C., Arblaster, J., Washington, W. M., Boyle, J. S., and Brüggemann, W.: Contributions of anthropogenic and natural forcing to recent tropopause height changes, Science, 301, 479-483, https://doi.org/10.1126/science.1084123, 2003.

Stohl, A., Spichtinger-Rakowsky, N., Bonasoni, P., Feldmann, H., Memmesheimer, M., Scheel, H. E., Trickl, T., Hubener, S., Ringer, W., and Mandl, M.: The influence of stratospheric intrusions on alpine ozone concentrations, Atmos. Environ., 34, 1323-1354, 2000.

Telford, P. J., Abraham, N. L., Archibald, A. T., Braesicke, P., Dalvi, M., Morgenstern, O., O’Connor, F. M., Richards, N. A. D., and Pyle, J. A.: Implementation of the Fast-JX Photolysis scheme (v6.4) into the UKCA component of the MetUM chemistry-climate model (v7.3), Geosci. Model Dev., 6, 161177, https://doi.org/10.5194/gmd-6-161-2013, 2013.

Thompson, A. M.: The oxidizing capacity of the Earth's atmosphere: probable past and future changes, Science, 256, 11571165, 1992.

Volz, A. and Kley, D.: Evaluation of the Montsouris series of ozone measurements made in the nineteenth century, Nature, 332, 240 242, 1988.

WMO: Scientific Assessment of Ozone Depletion: 2010, Global Ozone Research and Monitoring Project, Geneva, Switzerland, Report No. 52, 2011. 
WMO: Scientific Assessment of Ozone Depletion: 2014, Global Ozone Research and Monitoring Project, Geneva, Switzerland, Report No. 55, 2014.

Zeng, G., Pyle, J. A., and Young, P. J.: Impact of climate change on tropospheric ozone and its global budgets, Atmos. Chem. Phys., 8, 369-387, https://doi.org/10.5194/acp-8-369-2008, 2008.

Zeng, G., Morgenstern, O., Braesicke, P., and Pyle, J. A.: Impact of stratospheric ozone recovery on tropospheric ozone and its budget, Geophys. Res. Lett., 37, L09805, https://doi.org/10.1029/2010GL042812, 2010.
Zeng, G., Williams, J. E., Fisher, J. A., Emmons, L. K., Jones, N. B., Morgenstern, O., Robinson, J., Smale, D., Paton-Walsh, C., and Griffith, D. W. T.: Multi-model simulation of CO and HCHO in the Southern Hemisphere: comparison with observations and impact of biogenic emissions, Atmos. Chem. Phys., 15, 72177245, https://doi.org/10.5194/acp-15-7217-2015, 2015. 